\title{
Invited review: Microbial evolution in raw-milk, long-ripened cheeses produced using undefined natural whey starters
}

\author{
Monica Gatti, ${ }^{1}{ }^{1}$ Benedetta Bottari, ${ }^{\star}$ Camilla Lazzi, ${ }^{*}$ Erasmo Neviani, ${ }^{\dagger} \dagger$ and Germano Mucchetti ${ }^{\star} \dagger$ \\ *Department of Food Science, University of Parma, Parco Area delle Scienze, 48/A, 43124 Parma, Italy \\ †Centro Multidisciplinare Interdipartimentale Lattiero Caseario (MILC), University of Parma, Parco Area delle Scienze, 85/A, 43124 Parma, Italy
}

\begin{abstract}
The robustness of the starter culture during cheese fermentation is enhanced by the presence of a rich consortium of microbes. Natural starters are consortia of microbes undoubtedly richer than selected starters. Among natural starters, natural whey starters (NWS) are the most common cultures currently used to produce different varieties of cheeses. Undefined NWS are typically used for Italian cooked, long-ripened, extrahard, raw milk cheeses, such as Parmigiano Reggiano and Grana Padano. Together with raw milk microbiota, NWS are responsible for most cheese characteristics. The microbial ecology of these 2 cheese varieties is based on a complex interaction among starter lactic acid bacteria (SLAB) and nonstarter lactic acid bacteria (NSLAB), which are characterized by their different abilities to grow in a changing substrate. This review aims to summarize the latest findings on Parmigiano Reggiano and Grana Padano to better understand the dynamics of SLAB, which mainly arise from NWS, and NSLAB, which mainly arise from raw milk, and their possible role in determining the characteristics of these cheeses. The review is presented in 4 main sections. The first summarizes the main microbiological and chemical properties of the ripened cheese as determined by cheese-making process variables, as these variables may affect microbial growth. The second describes the microbiota of raw milk as affected by specific milk treatments, from milking to the filling of the cheese milk vat. The third describes the microbiota of NWS, and the fourth reviews the knowledge available on microbial dynamics from curd to ripened cheese. As the dynamics and functionality of complex undefined NWS is one of the most important areas of focus in current food microbiology research, this review may serve as a good starting point for implementing future studies on microbial diversity and functionality of undefined cheese starter cultures.
\end{abstract}

Received June 26, 2013.

Accepted October 9, 2013.

${ }^{1}$ Corresponding author: monica.gatti@unipr.it
Key words: raw milk cheese, microbial evolution, natural whey starter

\section{INTRODUCTION}

In the early twentieth century, the industrialization and commercialization of fermented food necessitated the need to turn traditional fermentation processes into controlled and rationalized food processing. Moreover, the food and beverage industry is rediscovering fermentation as a crucial step in product innovation (Hugenholtz, 2013). With this aim, fermentation research in food microbiology has focused on the isolation and phenotypic characterization of microbes originating from natural sources, such as spontaneous fermentation. This approach has delivered defined single and mixed-strain cultures suitable for industrial applications (Kutahya and Smid, 2012). However, the production of selected dairy starter cultures has been met with several obstacles, such as limitations in carbon and nitrogen source availability, salt stress during brining, temperature fluctuations, $\mathrm{pH}$ changes, and phage predation during cheese fermentation (Kutahya and Smid, 2012). Sensitivity to those factors can be essential for proper flavor formation. The robustness of the starter culture during cheese fermentation is enhanced by the presence of a rich consortium of microbes. Diversity in the starter culture is determined by different phenotypic characteristics linked to the coexistence of different genomic lineages of microbes. The genetic diversity present in wild strains includes a variety of features that are relevant to the improvement of starter cultures (Smid and Hugenholtz, 2010), and this diversity is selectively propagated as a result of adaptation by the microbes to dynamic environments.

For these reasons, the study of the dynamics and functionality of complex undefined starter cultures is one of the most important areas of focus in current food microbiology research. The dynamics of the biochemical activities, growth, survival, and death of microorganisms in fermented foods are the result of interactions between microbes and their microenvironment. This microenvironment exists in an unsteady state due to 
chemical and physical changes partly resulting from the microbes' own metabolic activities, which can be further manipulated by the sequence of operations in the food technology industry.

The fundamentals of the microbial ecology of longripened cheese produced from raw milk using undefined whey starter cultures are based on complex interactions among starter lactic acid bacteria (SLAB) and nonstarter lactic acid bacteria (NSLAB), which are characterized by their different abilities to grow in a changing substrate. The various steps of cheese-making induce heat-related, acidic, osmotic, and oxidative stresses on microorganisms and are responsible for alterations in heat load, $\mathrm{pH}$, water activity $\left(\mathbf{a}_{\mathbf{w}}\right)$, and redox potential gradients in the matrix (Beresford et al., 2001). As a consequence, SLAB viability is reduced within a few hours or a few days from the start of the cheese-making process, at which point a sizable fraction of the starter cells undergo autolysis, releasing their enzymes into the matrix. In contrast, NSLAB, which are able to grow using energy sources other than lactose and are more resistant to environmental stresses, grow slowly and become the dominant microflora of the ripened cheese. The ratio between SLAB and NSLAB is modulated by the type of culture added to the cheese milk, the cheese-making conditions, and the duration of cheese ripening.

Grana Padano (GP) and Parmigiano Reggiano (PR) cheeses are typical extra-hard, cooked Italian Protected Designation of Origin (PDO) cheeses characterized by a very long ripening period (a minimum of 9 and 12 mo for GP and PR, respectively) of up to 20 to 24 mo and often more than 30 mo in the case of gold-label PR cheese.

This long ripening period is common to other minor Italian cheeses produced in the mountainous areas of northern Italy, such as Bagoss from Bagolino (Brescia) and Nostrano Valtrompia PDO (Mucchetti and Neviani, 2006). Several other Italian cheeses such as Asiago d'Allevo, Montasio, Pecorino Romano, and Fiore Sardo PDO are ripened for $1 \mathrm{yr}$ or more (Gobbetti, 2004), although the typical ripening time for these cheeses is substantially less.

More famous long-ripened cheeses from Europe such as Swiss cheeses, Emmental, Gruyere, Sbrinz, Hobelkäse, and Comté are usually ripened for 6 to 48 mo (Depouilly et al., 2004; Harbutt, 2009; Turgay et al., 2011). Some other cheese varieties such as the Scandinavian Västerbottenost, Prästost, Herrgärdsost, Danbo, or Jarlsberg cheeses or the Low Countries' Postel and Leisde Kaas, or some varieties of old Edam and old Gouda cheese are ripened up to 36 mo (Harbutt, 2009). West Country Farmhouse Cheddar PDO cheese, produced in the United Kingdom, is aged for a mini- mum of $9 \mathrm{mo}$, with extra mature or vintage varieties being aged for more than 18 mo.

Natural starters, particularly natural whey starters (NWS), are the most common undefined cultures currently used to produce different varieties of cheeses, including PR, GP, Provolone Valpadana, Mozzarella di Bufala Campana, and Pecorino Romano cheeses in Italy and Comté and Gruyere cheeses in France and Switzerland.

Parmigiano Reggiano and GP cheeses are unmatched among world cheeses, and this review aims to summarize the latest findings on these 2 varieties to better understand the dynamics of SLAB and NSLAB and their role in determining the characteristics of these cheeses. This knowledge may serve as a good starting point for implementing future studies on microbial diversity and functionality of undefined cheese starter cultures.

\section{PARMIGIANO REGGIANO AND GRANA PADANO: MAJOR CHARACTERISTICS AND CHEESE-MAKING TECHNOLOGY}

\section{Chemical Composition of Ripened Cheeses}

Parmigiano Reggiano and GP cheeses have many common characteristics and some distinct properties. Although the similarities between these cheeses are defined by their similar cheese-making technologies, the differences are largely determined by the methods of milk collection, milk management before coagulation, and by the ripening conditions.

The moisture content of $\mathrm{PR}$ and GP cheeses ranges from 28 to $35 \%$ and varies according to ripening time; the ratio of fat to protein in PR and GP is quite variable and may be $0.94 \pm 0.02$ according to cheese milk characteristics. It is notable that PR and GP cheeses are lactose- and galactose-free, and the lactic acid content is approximately $1.5 \%$. Both isomers of lactic acid are present, with an L-to-D ratio of approximately 1.1 (Careri et al., 1996; De Dea Lindner et al., 2008).

Some minor carbohydrates, such as glycosaminoglycans, have been found in PR at levels of 1.5 to $3.0 \mathrm{mg} /$ $\mathrm{kg}$ (Coppa et al., 2012). Citric acid was found at levels ranging from 8 to $93 \mathrm{mg} / 100 \mathrm{~g}$, with an average value of $50 \mathrm{mg} / 100 \mathrm{~g}$ in PR (Careri et al., 1996; Coppola et al., 2000; De Dea Lindner et al., 2008). Organic acids derived from bacterial fermentation, such as acetic and propionic acid, are also present in low levels, usually $<100$ and $0.5 \mathrm{mg} / 100 \mathrm{~g}$, respectively, in PR (Tosi et al., 2008). A threshold of $2 \mathrm{mg}$ of propionic acid/100 g of cheese was proposed by Bacci et al. (2002) as a marker for evidence of a defect in PR cheese. In contrast, butyric acid can be generated during fermentation or lipolysis, and its threshold for nondefective PR cheeses 
can be as high as $120 \mathrm{mg} / 100 \mathrm{~g}$, even though this level is usually $<50 \mathrm{mg} / 100 \mathrm{~g}$ (Tosi et al., 2008; Malacarne et al., 2009). The overall mineral content of PR and GP cheeses is 4.0 to $4.5 \%$ and is characterized by the presence of added $\mathrm{NaCl}$ at a level of approximately $1.5 \%$.

Long ripening times allow for extensive proteolysis of casein molecules by the synergistic actions of plasmin, cathepsins, and SLAB and NSLAB proteases and peptidases. The contribution of rennet to casein proteolysis during ripening of PR and GP cheeses is controversial and likely depends on chymosin and pepsin inactivation by the heat load applied during cheese-making (Mucchetti and Neviani, 2006).

The traditional indices of proteolysis, based on the ratio between nitrogen fractions and total nitrogen, are largely used to quantify proteolysis in PR and GP cheeses. These indices show that more than one-third of cheese proteins are hydrolyzed to a large extent due to interactions among the above-cited enzymatic systems and the long ripening times.

Free amino acids (FAA), the products of microbial peptidases, represent more than $15 \%$ of the total protein content of PR and GP cheeses and increase with ripening time. Specific ratios among some FAA or their derivatives to total FAA are used as quality markers to distinguish grated PR and GP cheeses from imitation products (Resmini et al., 1985; Pellegrino and Hogenboom, 2007; Cattaneo et al., 2008). The amino acid pyroglutamic acid (pGlu) occurs in both PR and GP cheeses and increases during ripening; alone or together with certain peptides, this amino acid was proposed as a possible marker of ripening time (Panari, 1985; Careri et al., 1996; Mucchetti et al., 2000; Masotti et al., 2010).

Advances in proteomics have made available much information on the specific peptides present in ripened cheeses, allowing for the identification of peptides that are more resistant to further proteolysis (Sforza et al., 2012). These advances have also led to a greater understanding of the accumulation of nonproteolytic aminoacyl derivatives, such as $N$ - $\gamma$-glutamyl, $N$-pyroglutamyl, and $N$-lactoyl amino acids, which are involved in the development of the pleasant flavor of aged cheese (Sforza et al., 2009; Sgarbi et al., 2013a).

Free fatty acids are relatively abundant (up to 3.5 $\mathrm{g} / 100 \mathrm{~g}$ ) in PR and GP ripened cheeses, occurring mainly in the outer part of the cheese wheel (Malacarne et al., 2009). Butyric acid and short-chain fatty acids (SCFA) represent up to $7.1 \%$ of total FFA for both PR and GP cheeses (Malacarne et al., 2009; Prandini et al., 2009), a proportion lower than that present in milk fat; SCFA contribute to piquant taste of cheeses. Piquant taste, however, is not characteristic for PR and GP cheeses, according to the low level of SCFA, and for this reason lipolysis is usually recognized as a noncharacteristic occurrence in Italian hard cooked cheese varieties, despite of the abundance of the total amount of FFA.

\section{Microbiological Characteristics of Ripened Cheese}

Until the latter half of the 1990s, long-ripened Italian hard cooked cheeses were largely considered to be free of viable lactic acid bacteria (LAB) after the first 6 mo of ripening, with the exception of the presence of pediococci (Bottazzi, 1993; Neviani and Carini, 1994). Despite the long ripening times, both $\mathrm{PR}$ and GP cheeses harbor a viable microflora at the end of ripening, mainly composed of NSLAB originating from the raw milk. The LAB counts from 6 GP cheeses aged 13 mo were, on average, $4.53 \mathrm{log} \mathrm{cfu} / \mathrm{g}$ in de Man, Rogosa and Sharpe (MRS) agar and $4.82 \mathrm{log} \mathrm{cfu} / \mathrm{g}$ in cheese agar medium (CAM; Santarelli et al., 2013a). Grana Padano cheese aged 9 mo from the Trentino region (Trentino Grana) showed LAB counts in MRS up to $6.6 \mathrm{log} \mathrm{cfu} / \mathrm{g}$ and counts of $<5 \mathrm{log} \mathrm{cfu} / \mathrm{g}$ by $18 \mathrm{mo}$ of ripening (Monfredini et al., 2012). The LAB counts of 230-d-ripened Comté cheese, for which the curd was cooked at $56^{\circ} \mathrm{C}$ for $25 \mathrm{~min}$, were comparable (Depouilly et al., 2004).

Rossi et al. (2012) analyzed Trentino Grana cheese and found LAB counts of approximately $4.5 \mathrm{log} \mathrm{cfu} / \mathrm{g}$ in 10-mo-old cheeses cultured in MRS and $6 \mathrm{log} \mathrm{cfu} / \mathrm{g}$ in 18-mo-old cheeses. Enterococci, which are not usually detected in the advanced stages of hard cooked cheese ripening, were the dominant microflora in these same samples, demonstrating a trend similar to that observed for LAB in MRS (Rossi et al., 2012). Coppola et al. (1997) showed that LAB were able to grow on MRS at $28^{\circ} \mathrm{C}$ at levels of approximately $10^{7}$ and $10^{4} \mathrm{cfu} / \mathrm{g}$ for PR cheeses aged 12 and 24 mo, respectively. Counts of cultivable microflora can be as high as $10^{6} \mathrm{cfu} / \mathrm{g}$ for PR cheeses aged $12 \mathrm{mo}$, with these counts decreasing to $10^{3}$ $\mathrm{cfu} / \mathrm{g}$ within $24 \mathrm{mo}$ of ripening (Gatti et al., 2008a). Large variability was observed as a function of the medium used to cultivate the microflora, with the highest values observed when CAM was utilized (Neviani et al., 2009). A microscopy-based count of viable cells present in PR cheese samples aged 12 to 20 mo using a LIVE/ DEAD BacLight Viability Kit (Molecular Probes Inc., Eugene, OR) showed values similar to those measured using CAM but that were approximately 1 log unit lower than the total count (De Dea Lindner et al., 2008). These findings suggest that a large number of dead cells are not lysed or autolysed during ripening, even though it is known that lysis of LAB starter cells starts within a few days of cheese-making.

Microbial counts in cheese differ according to the spatial coordinates of the samples taken from the cheese 
wheel. Although the external zone of PR cheese aged 12 to 20 mo was characterized by values lower than those of the inner zone (De Dea Lindner et al., 2008), counts for GP cheese aged 9 or 18 mo were higher for the external zones compared with the inner zone (Monfredini et al., 2012).

The number of microbes present in ripened cheeses is the result of 2 primary factors: the ability of the microbes (1) to survive the heat and acid stress during the first steps of cheese-making and (2) to grow using energy sources other than milk carbohydrates during the time of ripening, despite the decreasing $\mathrm{a}_{\mathrm{w}}$ value.

The species most frequently found in ripened cheeses were Lactobacillus rhamnosus, Lactobacillus casei, Lactobacillus paracasei, Lactobacillus harbinensis, and Pediococcus acidilactici (Gala et al., 2008; Gatti et al., 2008a; Monfredini et al., 2012; Solieri et al., 2012). Starter LAB were also occasionally detected and, among these, Lactobacillus delbrueckii ssp. bulgaricus was isolated from GP aged 9 mo (Monfredini et al., 2012), whereas Lactobacillus helveticus, Lactobacillus delbrueckii ssp. lactis, and Lactobacillus fermentum were detected but not isolated in PR cheese aged 12 mo (Gala et al., 2008; Solieri et al., 2012). Lactobacillus buchneri and Lactobacillus parabuchneri were also detected (Gala et al., 2008).

The prevalence of mesophilic lactobacilli and the notable absence of thermophilic SLAB is a common trait of hard cooked, long-ripened cheeses produced with a thermophilic starter, such as Gruyere and Comté (Depouilly et al., 2004; Casey et al., 2006). However, when the heat stress is lowered, it is possible to recover thermophilic SLAB in aged cheeses. Starter LAB were found in 240-d-ripened Pecorino Romano cheeses in which the curd was cooked only to $48^{\circ} \mathrm{C}$ (Mangia et al., 2011). Streptococcus thermophilus and Streptococcus macedonicus were isolated from Provolone del Monaco, a pasta filata cheese, after 9 mo of ripening (Aponte et al., 2008).

Sheehan et al. (2007) showed the influence of different curd cooking temperatures $\left(47,50\right.$, and $\left.53^{\circ} \mathrm{C}\right)$ on the growth rate of Lb. helveticus, Strep. thermophilus, and NSLAB, confirming that Strep. thermophilus is less resistant to heat than $L b$. helveticus.

Rossi et al. (2012), in contrast to Monfredini et al. (2012), reported the presence, in Trentino Grana cheese, of species commonly found in raw milk but never detected as viable cells in hard cooked Italian cheeses at a similar stage of ripening and under similar heat stress conditions. Among the "unusual" LAB, Strep. thermophilus was cited, whereas among non-LAB genera, several species belonging to coagulase-negative staphylococci were listed. Even though the potential reasons for the presence of these bacteria as viable cells after at least 10 mo of ripening were not discussed by the authors (Rossi et al., 2012), Staphylococcus spp. were also isolated from Provolone del Monaco cheese aged 9 mo (Aponte et al., 2008).

It is possible to discriminate between the effect of heat stress and the effect of the time of ripening by comparing the microflora present in Cheddar cheese with the microflora in cooked cheeses. Cheddar cheese, a long-ripened, uncooked hard cheese, is obtained by the addition of a mesophilic SLAB (mainly lactococci), sometimes integrated with a mesophilic NSLAB lactobacilli as an adjunct culture (Crow et al., 2001). The highest temperature reached by the Cheddar cheese curd grains during heating is 38 to $39^{\circ} \mathrm{C}$ for approximately $35 \mathrm{~min}$ (Lawrence et al., 2004). Nonstarter LAB (such as Lb. paracasei, Lb. rhamnosus, Pediococcus, Lactobacillus brevis, Lb. fermentum, Lactobacillus plantarum, and Lb. coryneformis ssp. coryneformis) replicate to approximately $10^{8} \mathrm{cfu} / \mathrm{g}$ within the first 3 mo of ripening and remain at approximately this level for 18 mo of ripening (Crow et al., 2001). Thus, the absence of heat stress may be responsible for the higher NSLAB amount.

Non-LAB microflora of ripened hard, cooked cheeses occur in low quantities and are usually associated with alternative genera or species. Pathogenic bacteria such as Listeria monocytogenes, Salmonella spp., Staphylococcus aureus, and Escherichia coli O157:H7 were absent from both PR and GP cheeses, even when experimentally added to raw milk during a challenge test (Panari et al., 2001, 2004; Mucchetti, 2005).

\section{Cheese-Making Technologies and Their Relationship with Compositional Changes from Curd to Ripened Cheese}

Since the formation of the European agreement on cheese denominations in 1951 in Stresa, Italy, both PR and GP cheeses have been commonly called "Grana" cheeses. The name "Grana" originates from the typical granular structure of the cheeses resulting from the cheese-making conditions. This structure results from the early cutting of soft coagulum and the rapid cooking of the cheese curd grains (Iezzi et al., 2012). The correct management of these 2 operations contributes to a habitat that facilitates the growth of the whey starter and the raw milk microflora, determining the absolute moisture content and the physical structure in which the microorganism microcolonies can grow. However, cheese milk microflora are potentially different for PR and GP milks because of the different management of the temperature of 
milk collection and milk holding before coagulation, as described below.

\section{Milk Collection and Management Before Coagulation}

Parmigiano Reggiano milk is collected twice a day at a temperature $\geq 18^{\circ} \mathrm{C}$, as stated by the production rules, but only the milk from the evening milking is partly skimmed by spontaneous flotation of milk fat globules at a temperature of approximately 16 to $18^{\circ} \mathrm{C}$ (CRPA, 2007). Up to $10 \%$ of the whole milk from the morning milking can be stored at a temperature $>10^{\circ} \mathrm{C}$ and then mixed with that of the following evening to be partially skimmed. In this way, the cheese-maker can better regulate the fat content of cheese milk, avoiding a cheese with a fat content that is too high and at the same time reducing the risk of losing the typical granular structure.

Grana Padano milk can be collected twice a day, but more often, when it is stored at a farm at a temperature $\geq 8^{\circ} \mathrm{C}$, it is collected once a day. The production standard commits dairies to skimming all the milk by spontaneous flotation at a temperature ranging from 8 to $20^{\circ} \mathrm{C}$ (the more frequent case) or to skimming only the evening milk. These choices can have a noticeable influence on the outcome of Trentino Grana cheese (Franciosi et al., 2011b; Endrizzi et al., 2012). Furthermore, most GP dairies add up to $25 \mathrm{mg} / \mathrm{kg}$ of lysozyme to their vat milk, whereas PR cheese is produced without any additives.

\section{Addition of NWS to Cheese Milk}

Whey starter is added to cheese milk at approximately 2.7 to $3.5 \%$; the actual quantity is traditionally determined by a formula that considers the increase in titratable acidity of the cheese milk given by the addition of the whey starter (Quadri, 1949). As a consequence, the acidity of the whey starter is a fundamental variable, determining the amount of starter and the amount of microbial cells added to the milk. Approximately $90 \%$ of more than 3,000 samples of whey starter used for PR production showed acidity values ranging from 28 to $33^{\circ} \mathrm{SH}$ (Soxhlet-Henkel degrees) $/ 50 \mathrm{~mL}$. The acidity of more than half of the samples was in the range of 29 to $31.5^{\circ} \mathrm{SH} / 50 \mathrm{~mL}$, and these cultures presented the highest LAB counts. A positive correlation between LAB count and the ability to acidify milk was also shown (Tosi et al., 2006).

Whey starter addition increases milk acidity by a factor of 0.7 to $0.9^{\circ} \mathrm{SH} / 50 \mathrm{~mL}$, reducing cheese milk $\mathrm{pH}$ to $6.39 \pm 0.04$ (data from Consorzio del Formaggio Parmigiano Reggiano), favoring calf rennet activity.

\section{Milk Renneting, Coagulum Cutting, Cooking of Cheese Curd Grains, and Final Sedimentation Under Hot Whey}

The management of cheese-making technology, from the moment of rennet addition to the submersion of cooked cheese curd under hot whey (Figure 1), is crucial to the development of PR and GP cheeses because these steps determine the heat stress exerted on the microorganisms and the amount of readily available energy and nutritional sources (lactose, nonprotein nitrogen, minerals, vitamins) for the microorganisms resistant to heat stress. These sources are related to the modulation of the amount of residual whey fraction in the cheese curd.

To accelerate whey syneresis, cheese curd grains with a small size and a distribution that is not too large must be obtained (Iezzi et al., 2012). This goal is achieved by cutting the coagulum when its consistency is very soft; the ratio between the hardening time and the gelation time of the para- $\kappa$-casein network is approximately 0.2 (G. Mucchetti, unpublished data). The curd grains are fast-cooked to 53 to $56^{\circ} \mathrm{C}$, which reduces their size by a factor of approximately 1.6 (Iezzi et al., 2012), and the grains then settle on the bottom of the vat, where they lie under hot whey for 40 to $70 \mathrm{~min}$. During this time, the curd grains fuse together and continue to drain off whey.

Whey syneresis during this step of cheese-making is described by changes in the composition of the GP curd from the moment of the cutting to its extraction from the vat (Mucchetti et al., 2012). The data show that cooking of curd grains causes a sharp increase in the total solids content of the curd from 21.6 to $37.5 \%$ and that submerging the curd under hot whey further contributes to whey drainage, increasing the total solids to $55.5 \%$. These findings are consistent with those described by Ferri et al. (1992) and Tedeschi et al. (1993) for PR cheese curds and by Lopez et al. (2005) for Emmental cheese.

The decrease in the lactose content to $1.5 \%$ during this step of GP cheese-making is mainly due to the selective concentration of total solids, not to lactic acid fermentation, as indicated by the small increase in lactic acid and galactose contents. Similar findings were described by De Dea Lindner et al. (2008) and previously by Mora et al. (1984) for PR cheese-making.

\section{Temperature Gradient of the Molded Curd}

Extraction of the cooked cheese curd from the vat determines the beginning temperature gradient within the molded curd, which increases by up to $15^{\circ} \mathrm{C}$ within $7 \mathrm{~h}$ 


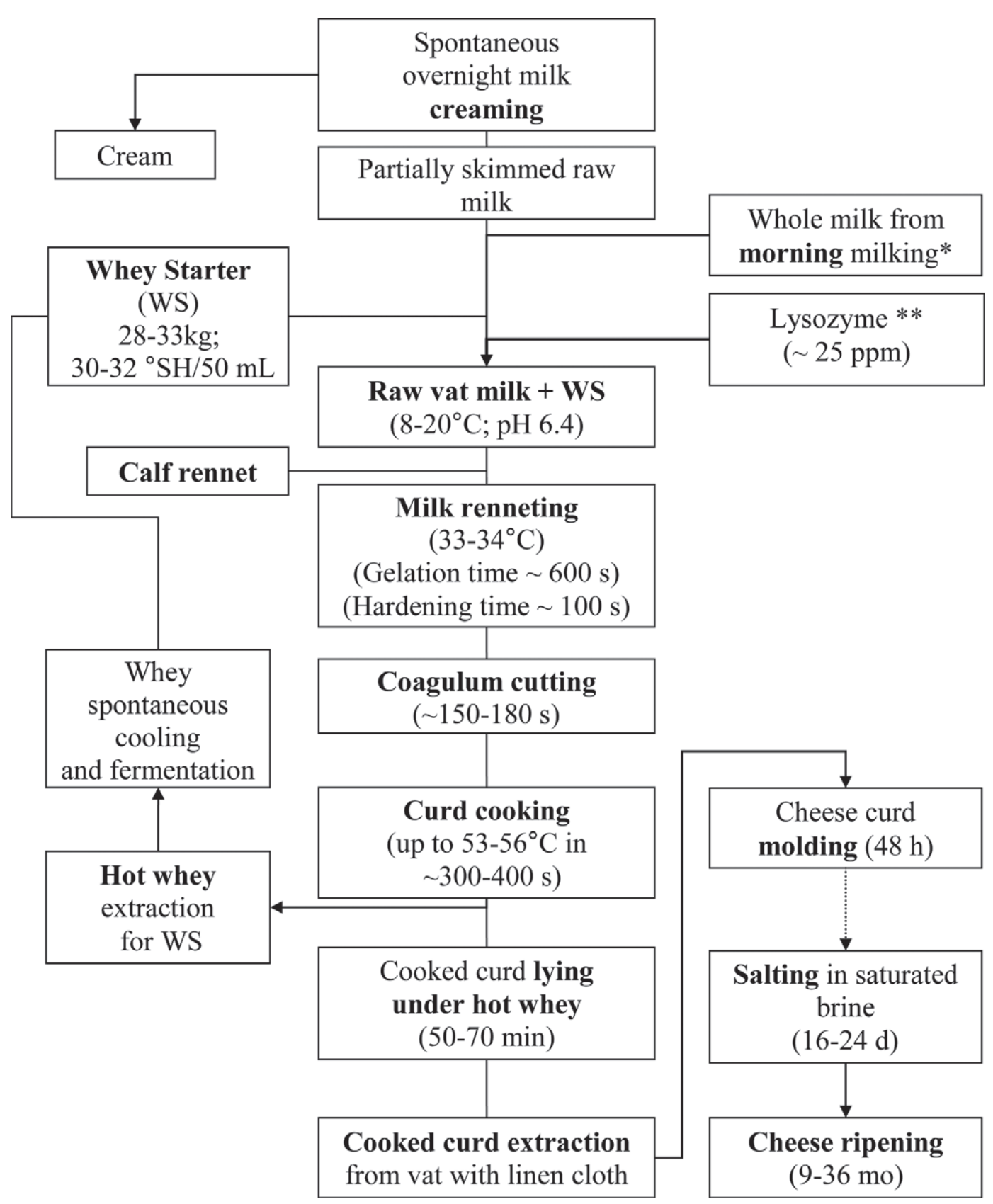

Figure 1. Flow sheet for Parmesan Reggiano (PR) and Grana Padano (GP) cheese-making. * Only for PR cheese; ${ }^{* *}$ only for GP cheese.

from molding (Mora et al., 1984; Giraffa et al., 1998b). This behavior was previously described for Swiss-type cheeses (Steffen et al., 1993). The parameters affecting the convective cooling of the cheese and temperature gradient formation were discussed by Ercolini et al. (2005) and Iezzi et al. (2011), who proposed different models for predicting temperature gradients.

The curd cooking temperature, room temperature, and size of the wheel are the main variables affecting the rate of the curd cooling and the heat-load gradient occurring within the wheel. Consequently, these factors affect the heat stress exerted on the LAB, other bacteria, and enzymes from the milk, rennet, and microorganisms. The temperature gradient generated by the unsteady cooling of the cooked molded curd first affects the rate of lactic acid fermentation, while galactose fermentation occurs more slowly in the inner zones, which is subjected to the highest heat stress; however, within $48 \mathrm{~h}$ of molding, all lactose and galactose is fermented (Mora et al., 1984; Addeo et al., 1997). Cheeses with a 
lower content of galactose are considered defective (Pellegrino et al., 1995; Santarelli et al., 2013b). The effects of the heat load gradient are also related to different characteristics of the ripened cheese, according to the distance of the zone of sampling from the wheel surface (Pellegrino et al., 1997; Malacarne et al., 2009).

The heat load gradient is believed to be responsible for the inactivation of rennet enzymes, which are known to contribute to casein proteolysis. When casein breakdown occurs more quickly, the work of microbial peptidases becomes easier. Rennet enzymes, plasmin, and cathepsin are nonmicrobial proteases involved in cheese ripening. Rennet inactivation is a key factor in addressing overall cheese proteolysis. However, studies on the residual activity of chymosin present in cheese extracts has yielded controversial results: Bansal et al. (2009) found that PR cheese extracts were able to hydrolyze synthetic substrates such as the heptapeptide Pro-Thr-Glu-Phe-[ $\mathrm{NO}_{2}$-Phe]-Arg-Leu, which is usually used to test rennet activity. Rampilli et al. (1998) did not measure rennet activity in GP extracts. In contrast, measuring the increase in the amount of $\alpha_{\mathrm{S}} \mathrm{CN} 24-199$ peptide in GP or PR cheeses as a marker of rennet activity did not provide definitive results. Gaiaschi et al. (2000) showed an increase in $\alpha_{\mathrm{S}_{1}}$-CN 24-199 peptide, resulting from the cleavage of the Phe23-Phe24 bond that is usually acted upon by chymosin during GP ripening. Finally, Sheehan et al. (2007) showed the occurrence of this peptide in cheeses obtained by curds cooked at $53^{\circ} \mathrm{C}$. However, the $\alpha_{\mathrm{S} 1}-\mathrm{CN} 24-199$ peptide may also be produced by cathepsin $\mathrm{D}$ or by a protease produced by Lb. helveticus (McSweeney et al., 1995; Gagnaire et al., 2001). The counter peptide $\alpha_{S^{-}}-\mathrm{CN} 1-23$ is hydrolyzed by many bacterial proteinases and peptidases both by thermophilic and mesophilic LAB (Kunij et al., 1996; Caira et al., 2003). Heat stress, in contrast, is responsible for the activation of plasminogen into plasmin and thus favors typical casein breakdown (Delacroix-Buchet and Fournier, 1992; Somers and Kelly, 2002; Pecorari et al., 2009).

Molding lasts for approximately 2 to $3 \mathrm{~d}$, during which the curd is placed in a plastic mold with a linen cloth on the first day to facilitate whey drainage. On the following day(s), a finely pierced steel mold is used.

\section{NWS Preparation}

Cheese curd cooking conditions determine the heat gradient that affects the whey starter preparation, although the cheese-maker can modify the cooling rate of the whey. The amount of culture necessary to produce GP and PR cheeses mainly depends on the size of the dairy. In 2012, the numbers of dairies producing GP and PR cheeses were 152 and 376, respectively. The average GP and PR dairy uses 47 and $14 \mathrm{t}$ of milk daily, respectively, resulting in a mean availability of whey starter culture of 1,400 and $400 \mathrm{~L} / \mathrm{d}$.

The traditional containers used to produce these cultures have a capacity of up to $70 \mathrm{~L}$ and are progressively substituted by larger containers that are often equipped with systems to control the fermentation temperature (CRPA, 2010). Whey is drawn up by self-priming pumps minutes after the sedimentation process of the cooked curd has ended and is subsequently delivered to the fermenters. Many dairies prefer to speed-cool the hot whey from the cooking temperature to 51 to $48^{\circ} \mathrm{C}$, with the aim of reducing heat stress and favoring the presence of Strep. thermophilus, in addition to the thermophilic homofermentative lactobacilli. Cooling can be allowed to occur spontaneously and regulated by natural convection or can be driven by the cheesemaker according to defined temperature gradients.

With the aim of improving biodiversity, the whey starter may be obtained from a mixture of two or more cultures made with different heat gradients. In this way, the resulting culture may better adapt to different milk qualities, unintended variations in the technological parameters of cheese-making, or the presence of phage.

\section{Cheese Brining and Ripening}

Both PR and GP cheeses are salted by brining for a length of time that depends on the size of the cheese, usually by dipping the wheels into saturated brines at room temperature for a period of 18 to $25 \mathrm{~d}$ (CRPA, 2007). The overall uptake of $\mathrm{NaCl}$ is approximately 1.5 $\mathrm{g} / 100 \mathrm{~g}$ of cheese, and the diffusion process of $\mathrm{NaCl}$ from the rind toward the inner zones is very slow. The distribution of $\mathrm{NaCl}$ across the wheel is not perfectly homogeneous during the first year of ripening (Resmini et al., 1974; Tosi et al., 2008; Malacarne et al., 2009).

The addition of $\mathrm{NaCl}$, together with the low-molecular-weight products of casein proteolysis, lowers the average $a_{w}$ value of PR cheese to 0.95 within $150 \mathrm{~d}$ (Coppola et al., 2000). A survey on $\mathrm{a}_{\mathrm{w}}$ values of GP cheeses ripened from 5 to $>24$ mo showed values ranging from 0.935 to 0.875 (L. Pellegrino, Department of Food, Environmental and Nutritional Sciences, University of Milan, Italy; personal communication). Analyses of $\mathrm{a}_{\mathrm{w}}$ on these same samples of the fraction corresponding to the underrind zone showed values from 0.915 to 0.845 .

The decrease of $\mathrm{a}_{\mathrm{w}}$ in PR and GP cheeses is substantially greater than that measured for Irish Cheddar cheese within $270 \mathrm{~d}$ of ripening, in which the $\mathrm{a}_{\mathrm{w}}$ was reduced from 0.964 to 0.956 (Hickey et al., 2013). The main differences between Cheddar cheese and PR and GP cheeses are related to the usually higher moisture content of Cheddar cheese and to the lower number of 
low-molecular-weight proteolysis products in Cheddar cheese $(1.8 \mathrm{~g}$ of FAA/100 $\mathrm{g}$ of cheese versus more than $4.5 \mathrm{~g} / 100 \mathrm{~g}$ for GP or PR cheeses). Monfredini et al. (2012) showed a difference in $\mathrm{a}_{\mathrm{w}}$ values between the underrind zone of Trentino Grana aged 9 mo and the inner zone ranging from 0.908 to 0.936 , confirming previous findings by Pellegrino et al. (1997) that showed a progressive increase in $\mathrm{a}_{\mathrm{w}}$ values as the distance from the rind increased. In the same paper, Pellegrino et al. (1997) showed that FAA content was higher near the surface than at the center of the wheel. In the zone directly under the rind, the FAA content was the lowest, likely due to the low $\mathrm{a}_{\mathrm{w}}$ values caused by the high total solids and $\mathrm{NaCl}$ content, which is able to modify the structure of $\beta$-casein and thus limit proteolysis (Fox and Walley, 1971).

Typically, both PR and GP cheeses are ripened in large warehouses with temperature and relative humidity $(\mathbf{R H})$ control to drive moisture loss and create a difference between the air RH and cheese surface $a_{w}$. Moisture evaporation during ripening contributes to lower $\mathrm{a}_{\mathrm{w}}$ values and facilitates microbial dynamics and enzymatic activities. The moisture content of PR and GP cheeses can decrease during ripening to values of 28 to $30 \%$ (Tosi et al., 2008).

The standard of production for GP cheeses establishes a temperature range between 15 and $22^{\circ} \mathrm{C}$, whereas that for $\mathrm{PR}$ does not define a temperature range, only specifying that in summer the temperature cannot be lower than $16^{\circ} \mathrm{C}$. Typically, the temperature of $\mathrm{PR}$ warehouses varies from 10 to $20^{\circ} \mathrm{C}$, with the most common temperatures being 14 to $16.5^{\circ} \mathrm{C}$; meanwhile, $\mathrm{RH}$ values range from 70 to $84 \%$ (Guidetti et al., 1995).

\section{MICROBIOTA OF RAW MILK}

\section{Microbiota of Raw Whole Milk for PR and GP Cheeses}

The microbiota of raw milk is first influenced by specific aspects of the farm environment, including the teat surface, air, dust, stable conditions, and milking parlor environment, which are responsible for milk contamination.

Raats et al. (2011) showed that the microbial community in milk farm samples differed significantly from that of dairy plant samples; the authors found that psychrotolerant communities, mainly Pseudomonadales, present in farm samples can proliferate during milk storage at refrigeration temperature. Pseudomonas spp. and pseudomonad counts can be related to the cleaning and sanitation procedures of milking equipment and to water quality (Leriche and Fayolle, 2012). Parameters used to clean milking equipment were strongly related to milk-derived psychrotrophic and coliform bacteria (Bava et al., 2011).

The isolation frequencies of the different species of lactobacilli in raw milk are quite different, with $L$. paracasei being the most frequently identified species (Vacheyrou et al., 2011). However, LAB are typically not a dominant species of raw milk microbiota.

Counts of raw milk spores of lactate-fermenting Clostridium spp. (butyric clostridia) are typically significantly low, ranging from 50 to $1.7 \times 10^{3} \mathrm{cfu} / \mathrm{L}$ (Ingham et al., 1998). Fontana et al. (2002) reported counts slightly higher, with values up to $1.3 \times 10^{4}$ spore/L for cow milk. Spore counts in milk collected in Lombardia (a region of northern Italy) from 2000 to 2012 showed mean values of less than $4 \times 10^{2}$ spore/L (IZSLER, 2013). Despite their low values compared with standard plate counts, the presence of butyric clostridia in milk is an important issue for cheese quality, as these bacteria are responsible for the reported late-blowing defect (Carini et al., 1985). It has been well established that Clostridium tyrobutyricum spores are the causative agent of the late-blowing defect in cheese (Klijn et al., 1995; Su and Ingham, 2000); more recently, Clostridium butyricum, Clostridium sporogenes, and Clostridium beijerinkij have also been found to be responsible for the same cheese defect (Cocolin et al., 2004; Le Bourhis et al., 2005; Garde et al., 2011, 2012).

The microbiota of raw whole milk may further change following its arrival at the dairy as a function of the different conditions (i.e., time and temperature) of storage of the milk at the farm and its collection from the farm to the dairy. These factors are determined by the European Regulation CE No 853/2004, on the hygiene of foodstuffs, and by the specific standard for PR and GP cheeses, as specified above.

\section{Microbiota of Raw Skim Milk After Spontaneous Creaming}

All milk used for GP cheese production and approximately half of that used for PR cheese production is subjected to a rest period of approximately 6 to $12 \mathrm{~h}$ to allow for partial spontaneous fat creaming to occur. During this time, the microbiota can change, depending on the equilibrium between 2 contrasting factors: the interaction among microbial cells and the milk fat globule membrane and the growth rate of bacteria.

The density of microbial cells is typically higher than that of skim milk, and as a consequence, these cells tend to sediment on the bottom of the milk container; typically, however, cream has a microbial count significantly higher than that of part skim milk or the original whole milk (Mucchetti and Neviani, 2006; Carminati et al., 2008; Franciosi et al., 2011a). 
Active mechanisms involving bacterial adhesion to milk fat globule membrane can be involved, in which glycosylated membrane proteins such as mucins or lactadherins (Lopez, 2011) can bind to bacteria (Sando et al., 2009; Guri et al., 2012). Additionally, various cell surface proteins and polysaccharides enable the adhesion of bacteria to interfaces. Effects due to the physical entrapment of bacteria within clusters of floating milk fat globules are also possible.

The temperature of milk is crucial, mainly because the temperature affects the microbial growth rate. Franciosi et al. (2011b) showed a general decrease in the microflora of skim milk after the milk was allowed to rest overnight at both ambient temperature and $12^{\circ} \mathrm{C}$. The unique exceptions to this decrease were the numbers of psychrotropic bacteria and enterococci, which were slightly higher after skimming at ambient temperature. The microbial counts in cream were higher than expected, as it was hypothesized that the microbial cells would be entrapped by the cream; this finding suggests that microbial growth is higher in cream than in skim milk. This trend was also shown by Battistotti and Rebecchi (1998). Carminati et al. (2008) showed the ability of raw milk LAB bacteria to grow both in skim milk and in cream kept at 15 or $20^{\circ} \mathrm{C}$ for $16 \mathrm{~h}$, with the highest values obtained for cream. Panari et al. (2007) found that microbial counts in skim milk are higher in the summer if the milk temperature is not controlled.

Pathogens can grow during spontaneous creaming of milk accordingly to milk temperature. At 8 and $15^{\circ} \mathrm{C}$, no growth of Listeria monocytogenes, Salmonella spp., E. coli O157:H7, or Staphylococcus aureus occurred within $16 \mathrm{~h}$, and the increased counts in the cream were due to the entrainment of the bacteria during cream separation. In contrast, these pathogens were able to grow at 20 and $25^{\circ} \mathrm{C}$ in both the partially skimmed raw milk and in the cream, and Staph. aureus produced staphylococcal enterotoxin only in the cream separated at $25^{\circ} \mathrm{C}$ (Carminati et al., 2008).

Spore counts of lactate-fermenting Clostridium spp. were significantly reduced up to $96 \%$ by spontaneous creaming (Panari et al., 2007), with an efficacy comparable to that when spores were separated by centrifugation at $9,000 \times g$ for $30 \mathrm{~s}$ ( $\mathrm{Su}$ and Ingham, 2000).

\section{Microbiota of Vat Cheese Milk}

The microbiota of vat cheese milk consists of both the microflora of the raw milk and that of the NWS. although in GP cheese-making, all of the milk is partially skimmed, in PR cheese-making, the milk from the morning milking is currently added to the vat without any fat separation. Therefore, the raw milk microbiota consists of both the microbiota from the evening milk- ing and the morning whole milk. In PR cheese-making, vat cheese milk contains the amount of thiocyanate $\left(\mathbf{S C N}^{-}\right)$naturally present in the morning milk, and the oxidation of this compound by the lactoperoxidase (LP) $-\mathrm{H}_{2} \mathrm{O}_{2}$ system is responsible for gram-negative bactericidal effects and for gram-positive bacteriostatic effects. The activity of the $\mathrm{LP}-\mathrm{SCN}^{-}-\mathrm{H}_{2} \mathrm{O}_{2}$ system is temperature-dependent, and the effects on the bacteria are stopped when all of the thiocyanate is oxidized $(4 \mathrm{~h}$ at $30^{\circ} \mathrm{C}$; Björck et al., 1975). It is possible that in GP milk, the LP-SCN ${ }^{-}-\mathrm{H}_{2} \mathrm{O}_{2}$ system is active only during the spontaneous milk skimming step.

To date, most GP dairies continue to add approximately $25 \mathrm{mg} / \mathrm{kg}$ of lysozyme to milk. The effect of lysozyme on raw milk and the whey starter microbiota is complex, particularly considering the biodiversity of the microbiota of the vat cheese milk (Carini et al., 1985). Different strains belonging to Lb. helveticus, the main species in NWS, show different sensibilities to lysozyme. This strain-specific resistance is thought to be due to the presence of an 11.5-kb plasmid (Veaux et al., 1991) acquired during strain adaptation and not by selection of spontaneous mutants (Neviani et al., 1991). Resistance of lactococci and lactobacilli to lysozyme (35 $\mathrm{mg} / \mathrm{kg}$ ) was demonstrated by Kozakova et al. (2005).

\section{MICROBIOTA OF NWS, AN UNDEFINED STARTER CULTURE}

The NWS used to produce GP and PR cheeses are undefined cultures that are traditionally prepared by retaining some of the whey drained from the cheese vat at the end of cheese-making. The temperature of curd cooking, the management of the gradient temperature during whey fermentation, and the increase in acidity each lead to the selection of a characteristic microbiota mainly consisting of thermophilic, aciduric, and moderately heat-resistant LAB (Rossetti et al., 2009; Gatti et al., 2011). Changing one or more of these parameters can lead to NWS with different characteristics (Santarelli et al., 2008). However, this modality of preparation also warrants the survival of different biotypes that are useful for the development of the ecosystem itself: a mixture of strains of the same species facilitates the development of a natural starter with a poorly defined composition but with a strong ability to self-adapt to variable technological performances, as required by nonstandardized cheese-making operations.

\section{NWS Counts}

Enumeration of LAB in GP and PR NWS has traditionally been performed by plate counts on different agars and media and more recently also by epifluores- 
cence microscopy (Bottari et al., 2006, 2010; Fornasari et al., 2006; Gatti et al., 2006). By comparing cultureindependent (i.e., microscopy) and culture-dependent (i.e., plate count) enumerations, it is clear that bacterial viability in NWS cannot be evaluated only as LAB capacity to form colonies on MRS or whey agar medium. The number of total cells, and in particular viable cells, was often higher (up to $1 \log$ unit) than the number of colony-forming units. Questions remain about such microbial populations that are viable but not cultivable, which often represent the majority of the culture. Because these bacteria are not able to growth in whey medium and cannot be isolated, the role of this population in the whey culture during cheese curd fermentation is not currently known.

To recover underestimated viable Strep. thermophilus from GP NWS, a revitalization step coupled with a modified M17 medium was used by Fornasari et al. (2006), who demonstrated the limitations related to the enumeration of streptococci using traditional M17 plating media.

The NWS of GP and PR showed a large distribution of LAB counts, ranging from $\sim 7.7$ to $9.9 \mathrm{log} \mathrm{cfu} /$ $\mathrm{mL}$ (Table 1). This variability appears to be dairy- or season-dependent and is not linked to cheese variety. Unusually low counts of $<7.0 \mathrm{log} \mathrm{cfu} / \mathrm{mL}$ were observed by Rossi et al. (2012) for Trentino Grana NWS.

\section{NWS LAB Species}

Dominant LAB species of GP and PR NWS, such as $L b$. helveticus and Lb. delbrueckii ssp. lactis, are thermophilic and homofermentative. Heterofermentative Lb. fermentum and Strep. thermophilus are also often found in NWS but at low frequencies and numbers (Zago et al., 2007a; Rossetti et al., 2008; Bottari et al.,
2010, 2013; Cremonesi et al., 2011; Monfredini et al., 2012; Pogačić et al., 2013; Santarelli et al., 2013a).

Techniques such as length heterogeneity (LH)-PCR and its correlated database were used to identify and semi-quantify the most abundant species, whereas fluorescence in situ hybridization (FISH) is a useful indicator of Lb. helveticus and Strep. thermophilus viability (Bottari et al., 2006, 2010). These approaches demonstrated that $L b$. helveticus was consistently found in the highest percentage in all NWS (for both GP and PR cheeses). Lactobacillus delbrueckii ssp. lactis was also commonly found but occurred in different percentages, whereas Lb. fermentum and Strep. thermophilus were only occasionally found in low percentages, with Strep. thermophilus occurring more frequently in GP NWS compared with PR NWS. The origin and the effect of the presence, or absence, of these different species, and the differences in the abundance of these species, have not yet been studied and therefore are not currently known.

Lactobacillus delbrueckii ssp. bulgaricus was found in NWS until the 2000s (Bottazzi et al., 2000; Coppola et al., 2000), but more recently, this species is no longer identified as a member of the microbiota of PR or GP NWS. Mesophilic species have been recovered in NWS at a low frequency, although the numbers of these microbes is consistently at least 3 or $4 \log$ lower than that of thermophilic species.

Lactobacillus rhamnosus, a facultatively heterofermentative mesophilic LAB, is the most frequently identified mesophilic LAB species in PR and GP NWS (Coppola et al., 2000; Neviani et al., 2009; Pogačić et al., 2013). Among the species less frequently identified, Lb. paracasei (Neviani et al., 2009; Rossi et al., 2012), Enterococcus faecium, and several species uncommon for the given environment such as Lactobacillus san-

Table 1. Thermophilic lactic acid bacteria (LAB) evaluated in natural whey starters

\begin{tabular}{|c|c|c|c|c|c|}
\hline \multirow[b]{2}{*}{ Cheese type } & \multicolumn{2}{|c|}{ Cultivable $\mathrm{LAB}^{1}(\log \mathrm{cfu} / \mathrm{mL})$} & \multirow{2}{*}{$\begin{array}{c}\text { Viable cells } \\
(\log \text { cells/mL) }\end{array}$} & \multirow{2}{*}{$\begin{array}{c}\text { No. of } \\
\text { samples }\end{array}$} & \multirow[b]{2}{*}{ Reference } \\
\hline & in MRS & in WAM & & & \\
\hline Parmigiano Reggiano & ND & $8.38-9.04$ & ND & 6 & Gatti et al., 2003 \\
\hline Parmigiano Reggiano & 7.00 & 8.50 & 9.50 & 1 & De Dea Lindner et al., 2008 \\
\hline Parmigiano Reggiano & ND & $8.03-8.77$ & $9.15-9.50$ & 18 & Bottari et al., 2010 \\
\hline Parmigiano Reggiano & ND & $7.70-8.98$ & $8.52-9.97$ & 18 & Santarelli et al., 2013b \\
\hline Grana Padano & ND & $8.15-9.29$ & $8.97-9.32$ & 8 & Fornasari et al., 2006 \\
\hline Grana Padano & ND & $8.39-9.29$ & $8.91-9.23$ & 23 & Gatti et al., 2006 \\
\hline Grana Padano & ND & $8.58-9.90$ & ND & 24 & Rossetti et al., 2008 \\
\hline Grana Padano & ND & $8.00-8.20$ & $8.90-9.20$ & 6 & Santarelli et al., 2013a \\
\hline Grana Trentino & ND & $5.00-7.00$ & & 5 & Rossi et al., 2012 \\
\hline Experimental Grana & 8 & ND & ND & 1 & Zago et al., 2007 \\
\hline
\end{tabular}

${ }^{1} \mathrm{MRS}=$ de Man, Rogosa, and Sharpe medium; WAM = whey agar medium.

${ }^{2}$ Not determined. 
franciscensis, Sphingomonas sp., and Staphylococcus epidermidis were identified only in Grana Trentino NWS by sequencing denaturing gradient gel electrophoresis-PCR bands (Rossi et al., 2012). It would be interesting to understand whether the identification of these unusual species is due to true microbiological differences among NWS or to the different detection limits of the methods used.

Denaturing gradient gel electrophoresis, which was used by Andrighetto et al. (2004), does not allow for the amplification of bands corresponding to $L b$. delbrueckii, Lb. fermentum, or Strep. thermophilus, even though these cultures were recognized, together with $L b$. helveticus, by culture-dependent methods. These data emphasize the sensitivity of these diverse microbiological methods.

Natural cultures used for Reggianito cheese-making in Argentina are mainly composed of $L b$. helveticus and Lb. delbrueckii ssp. lactis (Reinheimer et al., 1996) in an average proportion of 66 to $33 \%$. However, because Reggianito cheese curd is cooked at a maximum temperature of $51^{\circ} \mathrm{C}$ (SAGPyA, 2008), such strains would likely be unable to grow in Italian cheeses cooked at 54 to $55^{\circ} \mathrm{C}$.

Lactic acid bacteria species that are typically present in PR and GP NWS are different from those present in cultures used for Parmesan cheeses produced in the United States, which largely consist of selected strains of Strep. thermophilus and Lb. helveticus grown separately in skim milk (Govindasamy-Lucey et al., 2004).

Many studies have focused on the intraspecies (i.e., strain) characterization of the most abundant species isolated from NWS, showing how these cultures vary not only by species but also, and mainly, by strains within species. Because it is the dominant species in NWS, Lb. helveticus has been the focus of many studies regarding the phenotypic and genotypic biodiversity of this species. Biotypes isolated from the NWS used to produce GP were different from those isolated from the NWS used to produce Provolone cheese (Giraffa et al., 1998a, 2000; Gatti et al., 1999; Lombardi et al., 2002; Rossetti et al., 2009) and from those used to produce PR (Gatti et al., 2004). This diversity could be related to different cheese-making parameters that induce different selective pressures, particularly because Provolone cheese curd is usually cooked to a temperature $<52^{\circ} \mathrm{C}$ (Mucchetti and Neviani, 2006). However, biodiversity has also been found among biotypes isolated from the same niche. Gatti et al. (2004) highlighted the differences among $L b$. helveticus strains isolated from NWS collected from PR dairies located on plains and hills, whereas Lombardi et al. (2002) showed the differences among $L b$. helveticus strains isolated from NWS used to produce GP in the Lombardia and Veneto regions.
Few data are available regarding $L b$. delbrueckii ssp. lactis. It was observed that Lb. delbrueckii ssp. lactis biotypes isolated from PR NWS were comparable to those of GP NWS, whereas the biotypes isolated from Provolone NWS were distinct (Giraffa et al., 2003).

The biodiversity of $L b$. helveticus and $L b$. delbrueckii ssp. lactis isolated from GP and PR whey starter cultures was evaluated by Belletti and coauthors (2009) using 13 antibiotics. No significant differences relative to the type of cheese were found.

\section{NWS Microbial Interaction}

Based on intraspecies characterization, it is reasonable to assume that microbial composition in NWS is due not only to the species present but also to the different biotypes belonging to the same species; this difference is the crucial aspect that distinguishes natural cultures from select cultures. Moreover, this complexity is not stable but may be altered by the daily replacement of the culture. According to ecological principles, different bacterial interactions involving either stimulatory or inhibitory effects have been evaluated for $L b$. helveticus, Lb. delbrueckii ssp. lactis, and $L b$. fermentum. The growth of each strain, growing individually in whey containing cell-free supernatants of whey cultures from the other strains, was positively or negatively affected (Giraffa et al., 1997a). Giraffa et al. (1997a) observed that Lb. helveticus cultivated in microfiltered whey grows more efficiently if co-cultured with $L b$. delbrueckii ssp. lactis and Lb. delbrueckii ssp. bulgaricus, compared with single-strain whey cultures. The same authors also suggested that $L b$. helveticus can stimulate the growth of $L b$. delbrueckii ssp. lactis after $48 \mathrm{~h}$ of prolonged co-cultivation in whey.

However, the greatest advantage of NWS biological systems is undoubtedly their wide resistance to lytic bacteriophage attacks (Giraffa et al., 1997b). Despite extensive industry efforts, which include adapted factory designs, improved sanitation, adequate ventilation, process changes, improved starter mediums, and culture rotation, phage infection of starter LAB cultures remains one of the most common causes of slow or incomplete fermentation in the dairy industry (Garneau and Moineau, 2011; Marcó et al., 2012). Natural starters are widely considered to be highly tolerant to phage infection because they are grown in the presence of phages, which leads to dominance of resistant or tolerant strains (Marcó et al., 2012). The presence of various strains from the same species allows phage-infected single strains to be replaced by phage-resistant single strains with similar metabolic characteristics (Carminati et al., 2010). Although Carminati et al. (1997) found that lysogeny occurred in Lb. helveticus cultures 
isolated from GP NWS, these cultures were found to carry defective phages or killer particles when induced by mitomycin. More recently, a large number of $L b$. delbrueckii ssp. lactis lysogenic strains were isolated from NWS (Zago et al., 2007b). Suárez et al. (2008) confirmed that lysogeny is also present in $L b$. delbrueckii strains isolated from natural and commercial cultures.

\section{MICROBIAL EVOLUTION FROM CURD TO RIPENED CHEESE}

\section{LAB Evolution}

When NWS is added to partially skim milk in the vat, the microbiota in these cultures becomes mixed. The amount of NWS added is approximately 3\% (vol/ vol) of vat milk, thus the microbial equilibrium between NWS and milk favors the former, except in cases in which the LAB count of the NWS is unusually low, as reported by Rossi et al. (2012).

Lactic acid bacteria of cheese vat milk are usually differentiated as SLAB or NSLAB. The former are involved in lactic acid production during manufacture and contribute to the ripening process, whereas the latter do not contribute to acid production during manufacture but generally play a significant role during ripening (Beresford et al., 2001; Neviani and Gatti, 2013; Neviani et al., 2013). It is also common to distinguish these microbial groups according to their origin; SLAB mainly arise from the NWS, and NSLAB arise mainly from milk. However, the link that binds the milk and whey from which the NWS is prepared is very close, and thus it is also possible to find NSLAB in NWS. The NSLAB species Lb. rhamnosus was isolated from PR NWS (Neviani et al., 2009), whereas Lb. paracasei was isolated from Grana Trentino NWS (Rossi et al., 2012), and Pediococcus acidilactici was found in GP NWS (Pogačić et al., 2013).

During GP and PR cheese production, SLAB mainly develop in the molded curd within 12 to $24 \mathrm{~h}$ from curd extraction, and the growth of these microbes is coupled with lactic acid fermentation and a decrease in $\mathrm{pH}$ to approximately 5.10 to 5.25. The highest LAB counts are usually obtained from cheese curds harvested within 24 $\mathrm{h}$ of NWS addition and are in the range of $10^{8}$ to $10^{9}$ cfu/g (Santarelli et al., 2013b). Within $48 \mathrm{~h}$, the total LAB count starts to decrease, typically to levels $<10^{8}$ cfu/g (Santarelli et al., 2013a).

Microbial diversity in vat milk, NWS, and cheeses at different stages of ripening for GP cheese-making was measured using indices of diversity, evenness, and richness (Magurran, 2004; Buckland et al., 2005), calculated using the number of peaks and the area values resulting from LH-PCR electropherograms (Santarelli et al., 2013a). These indices were previously used to describe ecological diversity in environmental ecosystems (Ritchie et al., 2000; Kan et al., 2007) and to explore bacterial biodiversity during maize ensiling (Brusetti et al., 2006).

Among cheese ecosystems, distinct trends have been demonstrated, with a large biodiversity during the first $2 \mathrm{mo}$, followed by a gradual decrease during ripening. Richness, evenness, and diversity indices of bacterial community are estimated using the number and area of each peak in the LH-PCR electropherogram profiles. The highest number of species (identified and not identified) in the community (richness) is observed in 2-moold cheeses. This finding is consistent with the growth trend observed by culturing and could be correlated with the growth of NSLAB reported during the first month of ripening (Santarelli et al., 2013a).

\section{LAB and Curd Acidification}

During the first $24 \mathrm{~h}$ of cheese molding, the conversion of lactose into lactic acid is the main biochemical process that occurs in cheese. Acid production at the appropriate rate and time is a key step in the manufacture of a high-quality cheese.

The rate of $\mathrm{pH}$ decrease for PR and GP cheese curds occurs according to the following temperature gradient: the $\mathrm{pH}$ decreases to 5.1 to 5.2 within 5 to $6 \mathrm{~h}$ in the external zone, whereas the same $\mathrm{pH}$ value is reached only after $24 \mathrm{~h}$ from the addition of NWS to milk in the inner zone, which remains at a temperature $>50^{\circ} \mathrm{C}$ for more than $10 \mathrm{~h}$ (Pecorari et al., 2003). This $\mathrm{pH}$ decrease occurs in separate stages because of differences in LAB growth rates. Giraffa et al. (1998b) showed that the growth of the thermophilic lactobacilli was greatest between 0 and $6 \mathrm{~h}$ in the cheese exterior, where $L b$. helveticus predominated, and between 6 and $24 \mathrm{~h}$ in the core, where $L b$. delbrueckii became the dominant species. The identification method used in that study did not allow for identification of the subspecies. Lactobacillus delbrueckii ssp. lactis was undetectable in GP curds by colony hybridization (Zago et al., 2007a), whereas this species was found by LH-PCR in PR curd (Gatti et al., 2008a) and in GP curd (Pogačić et al., 2013; Santarelli et al., 2013a). Finally, Lb. fermentum, which is sometimes found in NWS, was also isolated from the curd between 6 and 48 h (Giraffa et al., 1998b). However, $L b$. fermentum biotypes isolated in GP curds were different from those isolated from NWS (Pogačić et al., 2013).

An abundance of Strep. thermophilus in NWS and the application of cheese-making parameters not optimal for thermophilic lactobacilli growth in curd can lead to significant differences in lactose and galactose fermentation and to a consequent lack of lactic acid pro- 
duction; these effects are due to the inability of Strep. thermophilus to ferment galactose and to the reduced contribution to lactose fermentation by lactobacilli. Santarelli et al. (2013b) found an inverse relationship between the galactose content of 18 PR cheese curds, sampled from 7 dairies at $24 \mathrm{~h}$ after vat extraction, and the number of cultivable thermophilic lactobacilli. In contrast, a positive correlation was observed between lactic acid content and thermophilic lactobacilli counts.

Moreover, when viable Strep. thermophilus were observed to be at least codominant with $L b$. helveticus in cheese curds by FISH, the curds were characterized by a high content of galactose and a low content of lactic acid (Santarelli et al., 2013b). However, no relation was found between NWS microbial species composition and the fermentation products of cheese curd. This lack of relation strengthens the hypothesis that when cheeses are produced with raw milk and NWS, the technological parameters applied to cheese-making are relevant to the outcome of the cheese, largely because these parameters are one the most powerful drivers of differentiated LAB growth.

Counts of LAB in PR and GP curds varied depending on the medium used, from $10^{7} \mathrm{cfu} / \mathrm{g}$ in PR (Coppola et al., 2000; Gatti et al., 2008a) and GP (Santarelli et al., 2013a) if evaluated with MRS in thermophilic conditions to $10^{8} \mathrm{cfu} / \mathrm{g}$ if evaluated with whey agar medium (De Dea Lindner et al., 2008; Gatti et al., 2008a), mainly in the external zone. Nonstarter LAB were detected in acidified curds at a low level, from $10^{3}$ to $10^{4} \mathrm{cfu} / \mathrm{g}$ in PR curds (Coppola et al., 2000; De Dea Lindner et al., 2008; Gatti et al., 2008a) and $10^{4} \mathrm{cfu} / \mathrm{g}$, on average, in GP curds (Santarelli et al., 2013a).

\section{LAB After Brining}

$\boldsymbol{S L A B}$. Starter LAB are undoubtedly the major players in the first hours of GP and PR production; however, after 18 to $25 \mathrm{~d}$ of brining, their counts drastically diminish as a consequence of the decrease of the availability of lactose and autolytic activities (Lortal et al., 1991; Wilkinson et al., 1994; Long et al., 1999; Lortal and Chapot-Chartier, 2005). Lactobacillus helveticus and $L b$. delbrueckii ssp. lactis cells were the dominant species through the second month of ripening, even though an increasing number of these cells underwent autolysis over time. Furthermore, lysozyme could accelerate the lysis of SLAB cells in GP cheese. Cell lysis is a key event for the release of cytoplasmic enzymes into the cheese matrix and is crucial to understanding the contribution of different microbial cells to cheese ripening. Although measuring the activities of intracellular enzymes such as lactate dehydrogenase or peptidases is traditionally used to assess cell lysis
(Bunthof et al., 2001), this method offers only general information and cannot provide information regarding the specific cells that are lysed. By studying PR cheesemaking during the first 20 mo of ripening, De Dea Lindner et al. (2008) found a negative correlation between total microbial counts and 4 peptidase activities. These peptidases showed 2 strong increases in activity: the first between 12 and $48 \mathrm{~h}$ and the second between mo 4 and 6 of ripening. These peaks in activity corresponded to the first decrease in SLAB count, reaching a maximum peptidase activity at $12 \mathrm{~h}$ from the start of cheese-making, and to the start of NSLAB lysis, as suggested by a study by Gatti et al. (2008b).

Gatti et al. (2008a) and Santarelli et al. (2013a) proposed an innovative method to study the dynamics of whole and lysed LAB cells during PR and GP ripening. These groups applied a semiquantitative, culture-independent LH-PCR method to cheese samples, analyzing the cheese extracts before and after sterilizing filtration (pore filter of $0.22 \mu \mathrm{m}$ ). Using this technique, DNA from whole and lysed cells could be differentiated by treating the whole-cell fraction with DNase to digest the free DNA arising from the lysed cells and analyzing the free-cell filtrate. Peak areas for SLAB whole cells decreased during PR cheese ripening, whereas peak areas for SLAB lysed cells increased in the first 6 mo of ripening. Even when thermophilic SLAB were detected as whole cells, these cells could not be isolated from cheeses during the first 2 mo of ripening, suggesting the presence of viable but uncultivable cells (Gatti et al., 2008a). This hypothesis was confirmed using direct epifluorescence microscopy (De Dea Lindner et al., 2008). After mo 24 of ripening, LH-PCR peak areas for SLAB whole and lysed cells were the smallest, suggesting the potential use of DNA as a source of carbon, nitrogen, phosphorus, and nucleic acids for less nutritionally demanding bacterial cells in the particularly hostile nutritional environment that exists during the advanced stages of cheese ripening (Gatti et al., 2008a).

Lysed cells of the SLAB Lb. helveticus and Lb. delbrueckii ssp. lactis were found in all 2-mo-old cheeses, confirming that starter lysis occurs following acidification (Santarelli et al., 2013a). Contrary to findings by Gatti et al. (2008a), who did not observe the presence of whole or lysed Lb. fermentum cells during PR cheese ripening, $L b$. fermentum lysed cells were observed in 2 GP cheese samples, for which high relative percentages were reported in one of these samples (Santarelli et al., 2013a). The isolation of Lb. fermentum from PR cheeses aged 12 mo suggests strong resistance to lysis by this species (Solieri et al., 2012).

NSLAB. The tolerance of NSLAB to hostile environments caused by absence of sugar, low $\mathrm{a}_{\mathrm{w}}$ value, and temperature lower than their optimal allows these 
microbes to develop after brining (Coppola et al., 1997, 2000; Cogan et al., 2007; Gatti et al., 2008a; Settanni and Moschetti, 2010; Neviani and Gatti 2013; Neviani et al., 2013).

Plate count methods attempting to differentiate thermophilic from mesophilic LAB using different incubation temperatures $\left(22\right.$ to $28^{\circ} \mathrm{C}$ vs. 42 to $45^{\circ} \mathrm{C}$ ) are not a good criteria for accurate data collection. Coppola et al. (1997) did not isolate thermophilic LAB from MRS plates incubated at $45^{\circ} \mathrm{C}$. Lactobacillus rhamnosus and $P$. acidilactici were isolated from MRS plates incubated at both 28 and $45^{\circ} \mathrm{C}$, whereas $L b$. casei and Lb. paracasei were more frequently isolated at $28^{\circ} \mathrm{C}$.

Growth curves of cultivable NSLAB have shown that the growth of these organisms peak between the mo 4 and 8 of cheese ripening, during which time the organisms increase by approximately 2 to 4 orders of magnitude relative to their initial count (Coppola et al., 1997; Zago et al., 2007a; Gatti et al., 2008a; Solieri et al., 2012).

Although it is well known that SLAB autolysis is greatly involved in cheese ripening, NSLAB autolysis has rarely been described in GP and PR ripening. Lysed Lb. rhamnosus or Lb. casei/paracasei were detected within the first 2 mo of GP ripening (Santarelli et al., 2013a), whereas NSLAB lysis during PR ripening began only after the first 6 mo (Gatti et al., 2008a). Early lysis of GP NSLAB may be related to the presence of added lysozymes. This hypothesis needs to be investigated by further researches.

In contrast to SLAB, which contribute to cheese ripening by releasing intracellular enzymes mostly in the early stages of aging, NSLAB play a key role in cheese ripening by multiplying after cheese brining and by release of enzymes into the cheese later in ripening.

Considering the highest numbers of SLAB (typically $>3 \times 10^{8} \mathrm{cfu} / \mathrm{g}$ ) and NSLAB (usually up to $5 \times 10^{7}$ $\mathrm{cfu} / \mathrm{g}$ ) in cheese and the different rates of lysis of these cells, it can be hypothesized that the contribution of NSLAB enzymes to cheese ripening is less than that of SLAB enzymes.

Characterization of NSLAB. The biodiversity of GP and PR NSLAB was evaluated by Belletti and colleagues (2009) by analyzing the susceptibility to 13 antibiotics of $L b$. rhamnosus and $L b$. casei isolated from ripened GP and PR cheese. Significant differences in antibiotic resistance were found among the strains in relation to the type of cheese. The strains isolated from $\mathrm{PR}$ in particular were more resistant to gentamicin and penicillin. The NSLAB strains were generally more resistant than SLAB strains, and significant differences were observed in their responses to different antibiotics. Moreover, PR-derived NSLAB showed greater resistance to gentamicin and penicillin compared with the same species isolated from ripened GP. The authors suggested that the different antibiotic profiles could be explained by farming conditions. Differences in geographical area, farm size, animal feed, and pasture can induce the need for different therapeutic antibiotic treatments. In such cases, the raw milk is believed to be the carrier of resistant NSLAB, which can develop antibiotic resistance on the farm. The different antibiotic resistances among cheese types observed for oxacillin, clindamycin, penicillin, and, above all, gentamicin can be explained by this theory.

To study Lb. rhamnosus evolution during PR ripening, 66 strains isolated during the same cheese-making session were genotypically characterized by Bove and colleagues (2011a). Interestingly, intraspecies heterogeneity correlates with the ability of bacteria to adapt to specific environmental conditions, a process driven by previous technological choices. The greatest number of different biotypes was isolated in the first period of cheese maturation; in particular, these biotypes were found in the curd after 6 and $48 \mathrm{~h}$ and in the cheese after brining. After this time, these biotypes were undetectable, perhaps due to the increasingly unfavorable conditions. In contrast, other biotypes were isolated only at the end of ripening. The majority of the strains belonged to biotypes that were present in cheese from the first or second month of ripening through at least mo 10. One of these biotypes was regularly isolated at each sampling time and therefore might be considered the dominant strain throughout the ripening process (Bove et al., 2011a).

Additionally, Solieri et al. (2012) verified an interesting biodiversity within the same species. Specifically, a culture-dependent, multiphasic approach was used to characterize NSLAB isolated from PR cheeses with different ripening times (from 7 to $23 \mathrm{mo}$ ) produced by several dairies. Lactobacillus rhamnosus and $L b$. paracasei were the species most frequently isolated, and among these species, an intraspecific diversity was revealed. Additionally in this study, the ripening time for both $L b$. rhamnosus and Lb. paracasei appeared to play a role in the composition of cultivable NSLAB in cheese.

The detection of different biotypes isolated from cheeses with different availabilities of nutrients due to the moment of ripening may suggest that these strains have specific metabolic properties.

On this subject, research has been conducted to evaluate the changes in $L b$. rhamnosus gene expression when this microbe is grown in a rich medium such as MRS compared with a cheese-like medium (CB; Bove et al., 2011b). Although Lb. rhamnosus strains isolated from 20-mo-ripened PR cheese grew more efficiently in MRS, these strains were also able to grow well in the 
more hostile cheese-like medium. This novel approach revealed that the transcriptomic profiles expressed by these microbes in cheese-like medium were more complex than previously thought. Complex metabolic pathways in the cell enabled the microbe to generate additional energy, allowing $L b$. rhamnosus to adapt to grow in unfavorable conditions (Bove et al., 2011b). It has also been demonstrated that $L b$. rhamnosus strains cultivated under cheese-like conditions expressed different levels of some proteins responsible for protein biosynthesis, nucleotide metabolism, carbohydrate metabolism, glycolysis, proteolytic activity, cell wall synthesis, exopolysaccharide biosynthesis, cell regulation, amino acid and citrate metabolism, oxidationreduction processes, and stress responses (Bove et al., 2012). Recently, it has been verified that NSLAB $L b$. rhamnosus and $L b$. casei grown in these conditions are capable of producing flavor compounds such as ketones, aldehydes, alcohols, and acids, which may contribute to PR organoleptic features (Sgarbi et al., 2013b).

\section{CONCLUSIONS}

Undefined natural whey cultures are typically used as starters for Italian cooked, long-ripened, raw milk cheeses, such as PR and GP. Together with raw milk, these starters are responsible for most cheese characteristics, first ensuring rapid and complete lactose fermentation and then contributing to casein proteolysis and to aroma and flavor development through amino acid catabolism. Although the variability in lactose fermentation is mainly time-dependent, being that all lactose is depleted within 24 to $48 \mathrm{~h}$ from the start of cheese-making, the variability in proteolysis is more complex and depends on the quantity and quality of LAB in the cheese and on the ability of the LAB to undergo autolysis. Furthermore, LAB proteolysis is strongly dependent on the primary proteolysis step performed by rennet and milk proteases. Attempts to produce defined whey starters have been made, but cheese-makers continue to prefer natural cultures and therefore have recently submitted requests to modify the PDO standards. The PR cheese standard states a clear ban on the use of selected starters (European Union, 2009), whereas the GP cheese standard (European Union, 2011) acknowledges the link between the use of natural whey, containing LAB typical of the area of origin of the cheese, and the unique characteristics of Grana Padano PDO cheese. In contrast to commodity cheeses, where selected starters are used to obtain the highest degree of cheese-making standardization and a highly reproducible product identity, PR and GP cheese producers accept slight variability in their products as a statement of their individual ability to manage wild populations of biodiverse microorganism in raw milk and whey starters, which offer a more personal mark on the cheese.

\section{REFERENCES}

Addeo, F., G. Mucchetti, and E. Neviani. 1997. Gli aspetti biochimici della maturazione del formaggio con particolare riferimento alle varietà a pasta dura. Sci. Tecn. Latt. Cas. 48:7-20.

Andrighetto, C., G. Marcazzan, and A. Lombardi. 2004. Use of RAPDPCR and TTGE for the evaluation of biodiversity of whey cultures for Grana Padano cheese. Lett. Appl. Microbiol. 38:400-405.

Aponte, M., V. Fusco, R. Andolfi, and S. Coppola. 2008. Lactic acid bacteria occurring during manufacture and ripening of Provolone del Monaco cheese: Detection by different analytical approaches. Int. Dairy J. 18:403-413.

Bacci, C., A. Paris, and F. Brindani. 2002. Ruolo di Clostridium spp. in alterazioni del Parmigiano Reggiano riconducibili a gonfiore tardivo. Ann. Fac. Med. Vet. Università di Parma. 22:221-231.

Bansal, N., P. F. Fox, and P. L. H. McSweeney. 2009. Comparison of the level of residual coagulant activity in different cheese varieties. J. Dairy Res. 76:290-293.

Battistotti, B., and A. Rebecchi. 1998. Panne di affioramento. Caratteristiche e mezzi di miglioramento. Il Latte 23:84-89.

Bava, L., M. Zucali, A. Sandrucci, M. Brasca, L. Vanoni, L. Zanini, and A. Tamburini. 2011. Effect of cleaning procedure and hygienic condition of milking equipment on bacterial count of bulk tank milk. J. Dairy Res. 78:211-219.

Belletti, N., M. Gatti, B. Bottari, E. Neviani, G. Tabanelli, and F. Gardini. 2009. Antibiotic resistance of lactobacilli isolated from two Italian hard cheeses. J. Food Prot. 72:2162-2169.

Beresford, T. P., N. A. Fitzsimons, N. L. Brennan, and T. M. Cogan. 2001. Recent advances in cheese microbiology. Int. Dairy J. 11:259-274.

Björck, L., C. G. Rosen, V. Marshall, and B. Reiter. 1975. Antibacterial activity of the lactoperoxidase system in milk against Pseudomonads and other gram-negative bacteria. Appl. Microbiol. 30:199-204.

Bottari, B., C. Agrimonti, M. Gatti, E. Neviani, and N. Marmiroli. 2013. Development of a multiplex real time PCR to detect thermophilic lactic acid bacteria in natural whey starters. Int. J. Food Microbiol. 160:290-297.

Bottari, B., D. Ercolini, M. Gatti, and E. Neviani. 2006. Application of FISH technology for microbiological analysis: Current state and prospects. Appl. Microbiol. Biotechnol. 73:485-494.

Bottari, B., M. Santarelli, E. Neviani, and M. Gatti. 2010. Natural whey starter for Parmigiano Reggiano: Culture-independent approach. J. Appl. Microbiol. 108:1676-1684.

Bottazzi, V. 1993. I batteri lattici nella maturazione del formaggio Grana. Ind. Latte 29:73-88.

Bottazzi, V., P. S. Cocconcelli, M. G. Parisi, and A. Rebecchi. 2000. Caratterizzazione biomolecolare di batteri lattici termofili del siero-fermento per Grana e indicazioni per un loro più razionale impiego. Sci. Tecn. Latt. Cas. 51:291-311.

Bove, C. G., M. De Angelis, M. Gatti, M. Calasso, E. Neviani, and M. Gobbetti. 2012. Metabolic and proteomic adaptation of Lactobacillus rhamnosus strains during growth under cheese-like environmental conditions compared to de Man, Rogosa, and Sharpe medium. Proteomics 12:3206-3218.

Bove, C. G., J. De Dea Lindner, C. Lazzi, M. Gatti, and E. Neviani. 2011a. Evaluation of genetic polymorphism among Lactobacillus rhamnosus non-starter Parmigiano Reggiano cheese strains. Int. J. Food Microbiol. 144:569-572.

Bove, C. G., C. Lazzi, V. Bernini, B. Bottari, E. Neviani, and M. Gatti. 2011b. cDNA-amplified fragment length polymorphism to study the transcriptional responses of Lactobacillus rhamnosus growing in cheese-like medium. J. Appl. Microbiol. 111:855-864.

Brusetti, L., S. Borin, D. Mora, A. Rizzi, N. Raddadi, C. Sorlini, and D. Daffonchio. 2006. Usefulness of length heterogeneity-PCR for monitoring lactic acid bacteria succession during maize ensiling. FEMS Microbiol. Ecol. 56:154-164. 
Buckland, S. T., A. E. Magurran, R. E. Green, and R. M. Fewster. 2005. Monitoring change in biodiversity through composite indices. Philos. Trans. R. Soc. Lond. B Biol. Sci. 360:243-254.

Bunthof, C. J., S. van Schalkwijk, W. Meijer, T. Abee, and J. Hugenholtz. 2001. Fluorescent method for monitoring cheese starter permeabilization and lysis. Appl. Environ. Microbiol. 67:4264-4271.

Caira, S., P. Ferranti, M. Gatti, M. E. Fornasari, F. Barone, S. Lilla, G. Mucchetti, G. Picariello, L. Chianese, E. Neviani, and F. Addeo. 2003. Synthetic peptides as substrate for assaying the proteolytic activity of Lactobacillus helveticus. J. Dairy Res. 70:315-325.

Careri, M., S. Spagnoli, G. Panari, M. Zannoni, and G. Barbieri. 1996. Chemical parameters of the non-volatile fraction of ripened Parmigiano-Reggiano cheese. Int. Dairy J. 6:147-155.

Carini, S., G. Mucchetti, and E. Neviani. 1985. Lysozyme: Activity against clostridia and use in cheese production - A review. Man (Lond) 3:299-320

Carminati, D., B. Bonvini, E. Neviani, and G. Mucchetti. 2008. The fate of potentially pathogenic bacteria during the preliminary steps of Grana cheesemaking: A laboratory-scale study on the natural creaming process of raw milk. Milchwissenschaft 63:416-419.

Carminati, D., G. Giraffa, A. Quiberoni, A. Binetti, V. Suárez, and J. Reinheimer. 2010. Advances and trends in starter cultures for dairy fermentations. Pages 177-192 in Biotechnology of Lactic Acid Bacteria: Novel Applications. F. Mozzi, R. Raya, and G. Vignolo, ed. Wiley-Blackwell, Ames, IA.

Carminati, D., L. Mazzucotelli, G. Giraffa, and E. Neviani. 1997. Incidence of inducible bacteriophage in Lactobacillus helveticus strains isolated from natural whey starter cultures. J. Dairy Sci. 80:1505-1511.

Casey, M. G., J. P. Häni, J. Gruskovnjak, W. Schaeren, and D. Wechsler. 2006. Characterisation of the non-starter lactic acid bacteria (NSLAB) of Gruyère PDO cheese. Lait 86:407-414.

Cattaneo, S., J. A. Hogenboom, F. Masotti, V. Rosi, L. Pellegrino, and P. Resmini. 2008. Grated Grana Padano cheese: New hints on how to control quality and recognize imitations. Dairy Sci. Technol. 88:595-605.

Cocolin, L., N. Innocente, M. Biasutti, and G. Comi. 2004. The late blowing in cheese: A new molecular approach based on PCR and DGGE to study the microbial ecology of the alteration process. Int. J. Food Microbiol. 90:83-91.

Cogan, T. M., T. P. Beresford, J. Steele, J. Broadbent, N. P. Shah, and Z. Ustunol. 2007. Invited review: Advances in starter cultures and cultured foods. J. Dairy Sci. 90:4005-4021.

Coppa, G. V., F. Maccari, L. Zampini, L. Santoro, T. Galeazzi, O. Gabrielli, and N. Volpi. 2012. Structural characterisation of chondroitin sulphate from Italian cheese Parmigiano-Reggiano. Food Chem. 134:195-199.

Coppola, R., M. Nanni, M. Iorizzo, A. Sorrentino, E. Sorrentino, C. Chiavari, and L. Grazia. 2000. Microbiological characteristics of Parmigiano Reggiano cheese during the cheesemaking and the first months of the ripening. Lait 80:479-490.

Coppola, R., M. Nanni, M. Iorizzo, A. Sorrentino, E. Sorrentino, and L. Grazia. 1997. Survey of lactic acid bacteria involved in the ripening of Parmigiano Reggiano cheese. J. Dairy Res. 64:305-310.

Cremonesi, P., L. Vanoni, S. Morandi, T. Silvetti, B. Castiglioni, and M. Brasca. 2011. Development of a pentaplex PCR assay for the simultaneous detection of Streptococcus thermophilus, Lactobacillus delbrueckii ssp. bulgaricus, L. delbrueckii ssp. lactis, L. helveticus, L. fermentum in whey starter for Grana Padano cheese. Int. J. Food Microbiol. 146:207-211.

Crow, V., B. Curry, and M. Hayes. 2001. The ecology of non-starter lactic acid bacteria (NSLAB) and their use as adjuncts in New Zealand Cheddar. Int. Dairy J. 11:275-283.

CRPA (Centro Ricerche Produzioni Animali). 2007. Conservazione e maturazione del latte per Parmigiano Reggiano. Opuscolo CRPA 3.37 N.6/2007. CRPA, Reggio Emilia, Italy.

CRPA (Centro Ricerche Produzioni Animali). 2010. Il sieroinnesto per Parmigiano Reggiano. Opuscolo CRPA 3.39 N.4/2010. CRPA, Reggio Emilia, Italy.

De Dea Lindner, J., V. Bernini, A. De Lorentiis, A. Pecorari, E. Neviani, and M. Gatti. 2008. Parmigiano-Reggiano cheese: Evolution of cultivable and total lactic microflora and peptidase activities during manufacture and ripening. Dairy Sci. Technol. 88:511-523.

Delacroix-Buchet, A., and S. Fournier. 1992. Proteolyse et texture des fromages à pate cuite presseé. II. Influence de la chymosine et des conditions de fabrication. Lait 72:53-72.

Depouilly, A., F. Dufrene, E. Beuvier, and F. Berthier. 2004. Genotypic characterisation of the dynamics of the lactic acid bacterial population of Comté cheese. Lait 84:155-167.

Endrizzi, I., A. Fabris, F. Biasioli, E. Aprea, E. Franciosi, E. Poznanski, A. Cavazza, and F. Gasperi. 2012. The effect of milk collection and storage conditions on the final quality of Trentingrana cheese: Sensory and instrumental evaluation. Int. Dairy J. 23:105-114.

Ercolini, D., V. Fusco, G. Blaiotta, F. Sarghini, and S. Coppola. 2005 Response of Escherichia coli O157:H7, Listeria monocytogenes, Salmonella typhimurium and Staphylococcus aureus to the thermal stress occurring in model manufactures of Grana Padano cheese. J. Dairy Sci. 88:3818-3825.

European Union. 2009. Amendment Application Council Regulation (EC) No 510/2006: Amendment application pursuant to Article 9: Parmigiano Reggiano. Accessed Nov. 22, 2013. http://eur-lex. europa.eu/LexUriServ/LexUriServ.do?uri=OJ:C:2009:087:0014:00 19:EN:PDF

European Union. 2011. Commission Implementing Regulation (EU) No 584/2011 of 17 June 2011 approving non-minor amendments to the specification for a name entered in the register of protected designations of origin and protected geographical indications [Grana Padano (PDO)]. Accessed Nov. 22, 2013. http://eur-lex. europa.eu/LexUriServ/LexUriServ.do?uri=OJ:L:2011:160:0065:00 70:EN:PDF

Ferri, G., A. Bagni, G. B. Castagnetti, G. Chiavari, L. Grazia, and G. Losi. 1992. Miniaturizzazione della fabbricazione del formaggio Grana: Standardizzazione del processo di caseificazione e delle condizioni relative alla prima fase di maturazione. Sci. Tecn. Latt. Cas. 43:427-441.

Fontana, M., S. Busiello, S. Bisotti, G. Dallorto, G. Unger, G. Schwameis, U. Juterschnig, B. Unger, H. Masaniger, and M. Schinkinger. 2002. Rapid enumeration of clostridial spores in raw milk samples using an impedimetric method. J. Rapid Methods Automat. Microbiol. 10:107-116.

Fornasari, M. E., L. Rossetti, D. Carminati, and G. Giraffa. 2006. Cultivability of Streptococcus thermophilus in Grana Padano cheese whey starters. FEMS Microbiol. Lett. 257:139-144.

Fox, P. F., and B. F. Walley. 1971. Influence of sodium chloride on the proteolysis of casein by rennet and by pepsin. J. Dairy Res. $38: 165-174$.

Franciosi, E., G. De Sabbata, F. Gardini, A. Cavazza, and E. Poznanski. 2011a. Changes in psychrotrophic microbial populations during milk creaming to produce Grana Trentino cheese. Food Microbiol. 28:43-51.

Franciosi, E., L. Settanni, N. Cologna, A. Cavazza, and E. Poznanski. 2011b. Microbial analysis of raw cows' milk used for cheesemaking: Influence of storage treatments on microbial composition and other technological traits. World J. Microbiol. Biotechnol. $27: 171-180$.

Gagnaire, V., D. Molle, M. Herrouin, and J. Leonil. 2001. Peptides identified during Emmental cheese ripening: Origin and proteolytic systems involved. J. Agric. Food Chem. 49:4402-4413.

Gaiaschi, A., B. Beretta, C. Poiesi, A. Conti, M. G. Giuffrida, C. L Galli, and P. Restani. 2000. Proteolysis of $\alpha$ s-casein as a marker of Grana Padano cheese ripening. J. Dairy Sci. 83:2733-2739.

Gala, E., S. Landi, L. Solieri, M. Nocetti, A. Pulvirenti, and P. Giudici. 2008. Diversity of lactic acid bacteria population in ripened Parmigiano Reggiano cheese. Int. J. Food Microbiol. 125:347-351.

Garde, S., R. Arias, P. Gaya, and M. Nuñez. 2011. Occurrence of Clostridium spp. in ovine milk and Manchego cheese with late blowing defect: identification and characterization of isolates. Int. Dairy J. 21:272-278.

Garde, S., P. Gaya, R. Arias, and M. Nuñez. 2012. Enhanced PFGE protocol to study the genomic diversity of Clostridium spp. isolated from Manchego cheeses with late blowing defect. Food Contr. 28:392-399. 
Garneau, J. E., and S. Moineau. 2011. Bacteriophages of lactic acid bacteria and their impact on milk fermentations. Microb. Cell Fact. 10(Suppl. 1):S20.

Gatti, M., V. Bernini, C. Lazzi, and E. Neviani. 2006. Fluorescence microscopy for studying the viability of micro-organisms in natural whey starters. Lett. Appl. Microbiol. 42:338-343.

Gatti, M., B. Bottari, M. Santarelli, and E. Neviani. 2011. Comparison of natural whey starters for Grana Padano cheese using sunray plots. Ann. Microbiol. 61:475-481.

Gatti, M., G. Contarini, and E. Neviani. 1999. Effectiveness of chemometrical techniques in discriminating Lactobacillus helveticus biotypes from natural dairy starter cultures by phenotypic characteristics. Appl. Environ. Microbiol. 65:1450-1454.

Gatti, M., J. De Dea Lindner, A. De Lorentiis, B. Bottari, M. Santarelli, V. Bernini, and E. Neviani. 2008a. Dynamics of whole and lysed bacterial cells during Parmigiano Reggiano cheese production and ripening. Appl. Environ. Microbiol. 74:6161-6167.

Gatti, M., J. De Dea Lindner, F. Gardini, G. Mucchetti, D. Bevacqua, M. E. Fornasari, and E. Neviani. 2008b. A model to assess lactic acid bacteria aminopeptidase activities in Parmigiano Reggiano cheese during ripening. J. Dairy Sci. 91:4129-4137.

Gatti, M., C. Lazzi, C. Rossetti, G. Mucchetti, and E. Neviani. 2003. Biodiversity in Lactobacillus helveticus strains in natural whey starter used for Parmigiano Reggiano cheese. J. Appl. Microbiol. 95:463-470.

Gatti, M., C. Trevisano, E. Fabrizi, E. Neviani, and F. Gardini. 2004. Biodiversity within Lactobacillus helveticus isolated from different natural whey starter cultures as revealed by classification trees. Appl. Environ. Microbiol. 70:182-190.

Giraffa, G., P. De Vecchi, and J. Reinheimer. 1997a. Population dynamics of thermophilic lactobacilli in mixed starter whey cultures. Food Res. Int. 37:137-140.

Giraffa, G., P. De Vecchi, P. Rossi, G. Nicastro, and M. G. Fortina. 1998a. Genotypic heterogeneity among Lactobacillus helveticus strains isolated from natural cheese starters. J. Appl. Microbiol. 85:411-416.

Giraffa, G., M. Gatti, L. Rossetti, L. Senini, and E. Neviani. 2000. Molecular diversity within Lactobacillus helveticus as revealed by genotypic characterization. Appl. Environ. Microbiol. 66:1259 1265.

Giraffa, G., C. Lazzi, M. Gatti, L. Rossetti, D. Mora, and E. Neviani. 2003. Molecular typing of Lactobacillus delbrueckii of dairy origin by RFLP of protein coding genes. Int. J. Food Microbiol. 82:163-172.

Giraffa, G., G. Mucchetti, F. Addeo, and E. Neviani. 1997b. Evolution of lactic acid microflora during Grana cheese-making and ripening. Man (Lond) 15:115-122.

Giraffa, G., L. Rossetti, G. Mucchetti, F. Addeo, and E. Neviani. 1998b. Influence of the temperature gradient on the growth of thermophilic lactobacilli used as natural starters in Grana cheese. J. Dairy Sci. 81:31-36.

Gobbetti, M. 2004. Extra hard varieties. Pages 52-70 in Cheese: Chemistry, Physics and Microbiology. Vol. 2. P. F. Fox, P. L. H. McSweeney, T. M. Cogan, and T. P. Guinee, ed. Elsevier Applied Science, Amsterdam, the Netherlands.

Govindasamy-Lucey, S., J. J. Jaeggi, A. L. Bostley, M. E. Johnson, and A. J. Lucey. 2004. Standardization of milk using cold ultrafiltration retentates for the manufacture of Parmesan cheese. J. Dairy Sci. 87:2789-2799.

Guidetti, R., R. Mora, and M. Zannoni. 1995. Influenza delle condizioni di stagionatura sul formaggio Parmigiano-Reggiano. Nota II: Formaggio conservato in magazzino con o senza climatizzazione. Sci. Tecn. Latt. Cas. 46:178-189.

Guri, A., M. Griffiths, C. M. Khursigara, and M. Corredig. 2012. The effect of milk fat globules on adherence and internalization of Salmonella enteritidis to HT-29 cells. J. Dairy Sci. 95:6937-6945.

Harbutt, J. 2009. World Cheese Book. DK Publishing, New York, NY.

Hickey, D. K., T. P. Guinee, J. Hou, and M. G. Wilkinson. 2013. Effects of variation in cheese composition and maturation on water activity in Cheddar cheese during ripening. Int. Dairy J. 30:53-58.
Hugenholtz, J. 2013. Traditional biotechnology for new foods and beverages. Curr. Opin. Biotechnol. 24:155-159.

Iezzi, R., S. Francolino, and G. Mucchetti. 2011. Natural convective cooling of cheese: Predictive model and validation of heat exchange simulation. J. Food Eng. 106:88-94.

Iezzi, R., F. Locci, R. Ghiglietti, C. Belingheri, S. Francolino, and G. Mucchetti. 2012. Parmigiano Reggiano and Grana Padano cheese curd grains size and distribution by image analysis. Lebenson. Wiss. Technol. 47:380-385.

Ingham, S. C., J. R. Hassler, Y.-W. Tsai, and B. H. Ingham. 1998. Differentiation of lactate-fermenting, gas-producing Clostridium spp. isolated from milk. Int. J. Food Microbiol. 43:173-183.

IZSLER (Istituto Zooprofilattico Sperimentale della Lombardia e dell'Emilia Romagna "Bruno Ubertini"). 2013. Sporigeni anaerobi. Accessed Apr. 15, 2013. http://www.izsler.it/pls/izs_bs/v3_s2ew_ consultazione.mostra_pagina?id_pagina $=529$.

Kan, J., M. T. Suzuki, K. Wang, S. E. Evans, and F. Chen. 2007. High temporal but low spatial heterogeneity of bacterioplankton in the Chesapeake Bay. Appl. Environ. Microbiol. 73:6776-6789.

Klijn, N., F. F. J. Nieuwenhof, J. D. Hoolwerf, C. B. Van Der Waals, and A. H. Weerkamp. 1995. Identification of Clostridium tyrobutyricum as the causative agent of late blowing in cheese by speciesspecific PCR amplification. Appl. Environ. Microbiol. 61:29192924 .

Kozakova, D., J. Holubova, M. Plockova, J. Chumchalova, and L. Curda. 2005. Impedance measurement of growth of lactic acid bacteria in the presence of nisin and lysozyme. Eur. Food Res. Technol. 221:774-778.

Kunji, E. R. S., I. Mierau, A. Hagting, B. Poolman, and W. N. Konings. 1996. The proteolytic system of lactic acid bacteria. Antonie van Leeuwenhoek 70:187-221.

Kutahya, O., and E. J. Smid. 2012. Microbial diversity and functionality of an undefined cheese starter culture. Accessed May 5, 2013 http://www.tifn.nl/webdb/publications/Microbial_diversity_ and_functionality_of_an_undefined_cheese_starter_culture.

Lawrence, R. C., J. Gilles, L. K. Creamer, V. L. Crow, H. A. Heap, C. G. Honoré, K. A. Johnston, and P. K. Samal. 2004. Cheddar cheese and related dry-salted cheese varieties. Pages 71-102 in Cheese: Chemistry, Physics and Microbiology. Major Cheese Groups. Vol. 2. P. F. Fox, P. L. H. McSweeney, T. M. Cogan, and T. P. Guinee, ed. Elsevier Applied Science, Amsterdam, the Netherlands.

Le Bourhis, A. G., K. Saunier, J. Dore, J. P. Carlier, J. F. Chamba, M. R. Popoff, and J. L. Tholozan. 2005. Development and validation of PCR primers to assess the diversity of Clostridium spp. in cheese by temporal temperature gradient gel electrophoresis. Appl. Environ. Microbiol. 71:29-38.

Leriche, F., and K. Fayolle. 2012. No seasonal effect on culturable pseudomonads in fresh milks from cattle herds. J. Dairy Sci. 95:2299-2306.

Lombardi, A., L. Dal Maistro, P. De Dea, M. Gatti, G. Giraffa, and E. Neviani. 2002. A polyphasic approach to highlight genotypic and phenotypic diversities of Lactobacillus helveticus strains isolated from dairy starter cultures and cheeses. J. Dairy Res. 69:139-149.

Long, M. V., R. Bizzarro, M. Gatti, and E. Neviani. 1999. The influence of temperature on the autolytic activity of thermophilic lactobacilli. Man (Lond.) 17:33-38.

Lopez, C. 2011. Milk fat globules enveloped by their biological membrane: Unique colloidal assemblies with a specific composition and structure. Curr. Opin. Colloid Interface Sci. 16:391-404.

Lopez, C., B. Camier, and J. Y. Gassi. 2005. Development of milk fat microstructure during the manufacture and ripening of Emmental cheese observed by confocal laser scanning microscopy. Int. Dairy J. $17: 235-247$.

Lortal, S., and M. P. Chapot-Chartier. 2005. Role, mechanisms and control of lactic acid bacteria lysis in cheese. Int. Dairy J. 15:857871

Lortal, S., M. Rousseau, P. Boyaval, and J. Van Heijenoort. 1991. Cell wall and autolytic system of Lactobacillus helveticus ATCC 12046. J. Gen. Microbiol. 137:549-559. 
Magurran, A. E. 2004 Measuring Biological Diversity. Blackwell Publishing, Oxford, UK.

Malacarne, M., A. Summer, P. Franceschi, P. Formaggioni, M. Pecorari, G. Panari, and P. Mariani. 2009. Free fatty acid profile of Parmigiano-Reggiano cheese throughout ripening: Comparison between the inner and outer regions of the wheel. Int. Dairy J. 19:637-641.

Mangia, N. P., M. A. Murgia, G. Garau, and P. Deiana. 2011. Microbiological and physicochemical properties of Pecorino Romano cheese produced using a selected starter culture. J. Agric. Sci. Technol. 13:585-600.

Marcó, M. B., S. Moineau, and A. Quiberoni. 2012. Bacteriophages and dairy fermentations. Bacteriophage 2:149-158.

Masotti, F., J. A. Hogenboom, V. Rosi, I. De Noni, and L. Pellegrino. 2010. Proteolysis indices related to cheese ripening and typicalness in PDO Grana Padano cheese. Int. Dairy J. 20:352-359.

McSweeney, P. L. H., P. F. Fox, and N. F. Olson. 1995. Proteolysis of bovine caseins by cathepsin D: Preliminary observations and comparison with chymosin. Int. Dairy J. 5:321-333.

Monfredini, L., L. Settanni, E. Poznanski, A. Cavazza, and E. Franciosi. 2012. The spatial distribution of bacteria in Grana-cheese during ripening. Syst. Appl. Microbiol. 35:54-63.

Mora, R., M. Nanni, and G. Panari. 1984. Variazioni chimiche, fisiche e microbiologiche nel formaggio Parmigiano Reggiano durante le prime 48 ore. Sci. Tecn. Latt. Cas. 35:20-32.

Mucchetti, G. 2005. Relazione finale del Coordinatore del Progetto CNR-MIUR "Sicurezza Formaggi Tipici Italiani -SiForTi" CNRMIUR. Accessed Apr. 15, 2013. http://www.pnragrobio.unina.it/ SIFORTI.html\#Risultati_Finali1.

Mucchetti, G., F. Addeo, and E. Neviani. 1998. Evoluzione storica della produzione di formaggi a Denominazione d'Origine Protetta (DOP). I. Pratiche di produzione, utilizzo e composizione dei sieroinnesti nella caseificazione a formaggi Grana Padano e Parmigiano Reggiano: Considerazioni sulle relazioni tra sieroinnesto e DOP. Sci. Tecn. Latt. Cas. 49:281-311.

Mucchetti, G., R. Iezzi, S. Francolino, and F. Locci. 2012. Le dimensioni dei granuli di cagliata di formaggi a pasta cotta e dura: Modalità di taglio del coagulo e cottura. Third Congr. Lattiero-Caseario, Milan, Italy. Accessed on Apr. 15, 2013. http://www.arca.regione. lombardia.it/shared/ccurl/24/39/Interventi\%20Aitel\%202012.pdf.

Mucchetti, G., F. Locci, M. Gatti, E. Neviani, F. Addeo, A. Dossena, and R. Marchelli. 2000. Pyroglutamic acid in cheese: Presence, origin, and correlation with ripening time of Grana Padano cheese J. Dairy Sci. 83:659-665.

Mucchetti, G., and E. Neviani. 2006. Microbiologia e tecnologia lattiero casearia. Qualità e Sicurezza. Tecniche Nuove Editore, Milano, Italy.

Neviani, E., B. Bottari, C. Lazzi, and M. Gatti. 2013. New developments in the study of the microbiota of raw-milk, long-ripened cheeses by molecular methods: The case of Grana Padano and Parmigiano Reggiano. Front. Microbiol. 4:1-14.

Neviani, E., and S. Carini. 1994. Microbiology of Parmesan cheese. Man (Lond) 12:1-8.

Neviani, E., D. Carminati, M. Veaux, J. Hermier, and G. Giraffa 1991. Characterization of Lactobacillus helveticus strains resistant to lysozyme. Lait 71:65-73.

Neviani, E., J. De Dea Lindner, V. Bernini, and M. Gatti. 2009. Recovery and differentiation of long ripened cheese microflora through a new cheese-based cultural medium. Food Microbiol. 26:240-245.

Neviani, E., and M. Gatti. 2013. Microbial evolution in raw-milk, longripened cheeses: Grana Padano and Parmigiano Reggiano case. Pages 133-148 in Cheese Ripening: Quality, Safety and Health Aspects. C. L. Randazzo, C. Caggia, E. Neviani, ed. Nova Science Publishers Inc., New York, NY.

Panari, G. 1985. L'acido lattico e l'acido piroglutammico nella maturazione del formaggio Parmigiano-Reggiano. Sci. Tecn. Latt. Cas. 36:98-109.

Panari, G., M. Pecorari, G. Merialdi, and M. Dottori. 2004. Il comportamento dei batteri potenzialmente patogeni nella produzione del Parmigiano-Reggiano. Sci. Tecn. Latt. Cas. 55:137-146.
Panari, G., S. Perini, R. Guidetti, M. Pecorari, G. Merialdi, and A. Albertini. 2001. Indagine sul comportamento di ceppi potenzialmente patogeni nella tecnologia del Parmigiano-Reggiano. Sci. Tecn. Latt. Cas. 52:13-22.

Panari, G., P. Reverberi, A. Caroli, M. Nocetti, and M. Pecorari. 2007. Le variazioni del profilo microbiologico del latte durante l'affioramento in diverse condizioni operative. Sci. Tecn. Latt. Cas. 58:83-93.

Pecorari, M., G. Gambini, A. Pecorari, F. Masotti, J. A. Hogenboom, L. Pellegrino, S. Ghidini, M. Malacarne, and P. Mariani. 2009. L'utilizzo di caldaie di rame o di acciaio: Effetti sulla tecnologia e sulle caratteristiche qualitative del Parmigiano Reggiano. Sci. Tecn. Latt. Cas. 60:97-118.

Pecorari, M., G. G. Gambini, P. Reverberi, and A. Caroli. 2003. L'influenza di alcuni fattori tecnologici sulla glicolisi del Parmigiano-Reggiano. Sci. Tecn. Latt. Cas. 54:287-299.

Pellegrino, L., G. Battelli, P. Resmini, P. Ferranti, F. Barone, and F. Addeo. 1997. Effects of heat load gradient occurring in moulding on characterization and ripening of Grana Padano. Lait 77:217228 .

Pellegrino, L., and J. A. Hogenboom. 2007. Verifica della validità del quadro degli amminoacidi liberi a 15 anni dalla sua introduzione per la caratterizzazione del Parmigiano-Reggiano. Sci. Tecn. Latt. Cas. 58:5-16.

Pellegrino, L., P. Resmini, and U. Fantuzzi. 1995. Evaluation and interpretation of alkaline phosphatase activity in the control of Grana Padano and Parmigiano Reggiano cheese. Industrie del Latte 31:17-30.

Pogačić, T., A. Mancini, M. Santarelli, B. Bottari, C. Lazzi, E. Neviani, and M. Gatti. 2013. Diversity and dynamic of lactic acid bacteria strains during aging of a long ripened hard cheese produced from raw milk and undefined natural starter. Food Microbiol. 36:207-215. http://dx.doi.org/10.1016/j.fm.2013.05.009.

Prandini, A., S. Sigolo, and G. Piva. 2009. Conjugated linoleic acid (CLA) and fatty acid composition of milk, curd and Grana Padano cheese in conventional and organic farming systems. J. Dairy Res. $76: 278-282$.

Quadri, P. 1949. La lavorazione del formaggio Grana. Latte 23:217218.

Raats, D., M. Offek, D. Minz, and M. Halpern. 2011. Molecular analysis of bacterial communities in raw cow milk and the impact of refrigeration on its structure and dynamics. Food Microbiol. $28: 465-471$

Rampilli, M., V. Raja, and A. L. Gatti. 1998. Valutazione dell'attività residua del caglio nel formaggio. Sci. Tecn. Latt. Cas. 49:29-41.

Reinheimer, J. A., A. Quiberoni, P. Tailliez, G. Binetti, and V. B. Suarez. 1996. The lactic acid microflora of natural whey starters used in Argentina for hard cheese production. Int. Dairy J. 6:869-879.

Resmini, P., L. Pellegrino, C. Pazzaglia, and J. A. Hogenboom. 1985 Gli amminoacidi liberi nella tipizzazione del formaggio Parmigiano-Reggiano ed in particolare del prodotto grattugiato. Sci. Tecn. Latt. Cas. 36:557-592.

Resmini, P., G. Volonterio, S. Annibaldi, and G. Ferri. 1974. Studio sulla diffusione del sale nel formaggio Parmigiano Reggiano mediante l'uso di $\mathrm{Na}^{36} \mathrm{Cl}$. Sci. Tecn. Latt. Cas. 25:149-166.

Ritchie, N. J., M. E. Schutter, R. P. Dick, and D. D. Myrold. 2000. Use of length heterogeneity pcr and fatty acid methyl ester profiles to characterize microbial communities in soil. Appl. Environ. Microbiol. 66:1668-1675.

Rossetti, L., D. Carminati, M. Zago, and G. Giraffa. 2009. A qualified presumption of safety approach for the safety assessment of Grana Padano whey starters. Int. J. Food Microbiol. 130:70-73.

Rossetti, L., M. E. Fornasari, M. Gatti, C. Lazzi, E. Neviani, and G. Giraffa. 2008. Grana Padano cheese whey starters: Microbial composition and strain distribution. Int. J. Food Microbiol. 127:168-171.

Rossi, F., V. Gatto, G. Sabattini, and S. Torriani. 2012. An assessment of factors characterising the microbiology of Grana Trentino cheese, a Grana-type cheese. Int. J. Dairy Technol. 65:401-409. 
SAGPyA (Secretaria de Agricultura, Ganaderia, Pesca y Alimentos). 2008. Resolución No. 16/2008. Protocolo de Calidad para Queso Reggianito. Accessed Jun. 13, 2013. http://www.inti.gov.ar/lacteos/pdf/queso_reggianito.pdf.

Sando, L., R. Pearson, C. Gray, P. Parker, P. Hawken, P. C. Thomson, J. R. S. Meadows, K. Kongsuwan, S. Smith, and R. L. Tellam. 2009. Bovine Muc1 is a highly polymorphic gene encoding an extensively glycosylated mucin that binds bacteria. J. Dairy Sci. 92:5276-5291.

Santarelli, M., B. Bottari, C. Lazzi, E. Neviani, and M. Gatti. 2013a. Survey on community and dynamics of lactic acid bacteria in Grana Padano cheese. Syst. Appl. Microbiol. 36:593-600. http:// dx.doi.org/10.1016/j.syapm.2013.04.007.

Santarelli, M., B. Bottari, M. Malacarne, C. Lazzi, S. Sforza, A. Summer, E. Neviani, and M. Gatti. 2013b. Variability of lactic acid production, chemical and microbiological characteristics in 24hour Parmigiano Reggiano cheese. Dairy Sci. Technol. 93:605621. http://dx.doi.org/10.1007/s13594-013-0130-9.

Santarelli, M., M. Gatti, C. Lazzi, V. Bernini, G. A. Zapparoli, and E. Neviani. 2008. Whey starter for Grana Padano cheese: Effect of technological parameters on viability and microbial community. J. Dairy Sci. 91:883-891.

Settanni, L., and G. Moschetti. 2010. Non-starter lactic acid bacteria used to improve cheese quality and provide health benefits. Food Microbiol. 27:691-697.

Sforza, S., V. Cavatorta, G. Galaverna, A. Dossena, and R. Marchelli. 2009. Accumulation of non-proteolytic aminoacyl derivatives in Parmigiano-Reggiano cheese during ripening. Int. Dairy J. 19:582-587.

Sforza, S., V. Cavatorta, F. Lambertini, G. Galaverna, A. Dossena, and R. Marchelli. 2012. Cheese peptidomics: A detailed study on the evolution of the oligopeptide fraction in Parmigiano-Reggiano cheese from curd to 24 months of aging. J. Dairy Sci. 95:35143526 .

Sgarbi, E., C. Lazzi, L. Iacopino, F. Lambertini, S. Sforza, and M. Gatti. 2013a. Microbial origin of non proteolytic aminoacyl derivatives in long ripened cheeses. Food Microbiol. 35:116-120.

Sgarbi, E., C. Lazzi, G. Tabanelli, M. Gatti, E. Neviani, and F. Gardini. 2013b. Non-starter lactic acid bacteria volatilomes produced using cheese component. J. Dairy Sci. 96:4223-4234.

Sheehan, J. J., M. A. Fenelon, M. G. Wilkinson, and P. L. H. McSweeney. 2007. Effect of cook temperature on starter and non-starter lactic acid bacteria viability, cheese composition and ripening indices of a semi-hard cheese manufactured using thermophilic cultures. Int. Dairy J. 17:704-716.

Smid, E. J., and J. Hugenholtz. 2010. Functional genomics for food fermentation processes. Annu. Rev. Food Sci. Technol. 1:497-519.

Solieri, L., A. Bianchi, and P. Giudici. 2012. Inventory of non starter lactic acid bacteria from ripened Parmigiano Reggiano cheese as assessed by a culture dependent multiphasic approach. Syst. Appl. Microbiol. 35:270-277.

Somers, J. M., and A. L. Kelly. 2002. Contribution of plasmin to primary proteolysis during ripening of cheese: Effect of milk heat treatment and cheese cooking temperature. Lait 82:181-191.

Steffen, C., P. Eberhard, J. O. Bosset, and M. Ruegg. 1993. Swisstype varieties. Pages 83-110 in Cheese: Chemistry, Physics and Microbiology. Vol. 2. P. F. Fox, ed. Chapman \& Hall, London, UK

Su, Y.-C., and S. C. Ingham. 2000. Influence of milk centrifugation, brining and ripening conditions in preventing gas formation by Clostridium spp. in Gouda cheese. Int. J. Food Microbiol. 54:147154

Suárez, V., M. Zago, A. Quiberoni, D. Carminati, G. Giraffa, and J. Reinheimer. 2008. Lysogeny in Lactobacillus delbrueckii strains and characterization of two new temperate prolate-headed bacteriophages. J. Appl. Microbiol. 105:1402-1411.

Tedeschi, G., F. Tosi, and M. Pecorari. 1993. La tecnologia di caseificazione del Parmigiano-Reggiano: Variabilità e rilievi analitici su latte, cagliata e siero. Sci. Tecn. Latt. Cas. 44:327-343.

Tosi, F. S. Sandri, E. Fossa, A. Summer, and M. S. Mariani. 2006. Variazioni stagionali delle caratteristiche analitiche del sieroinnesto naturale utilizzato nelle produzione di Parmigiano-Reggiano durante il 2004. Sci. Tecn. Latt. Cas. 57:87-104.

Tosi, F., S. Sandri, G. Tedeschi, M. Malacarne, and E. Fossa. 2008. Variazioni di composizione e proprietà fisico-chimiche del Parmigiano-Reggiano durante la maturazione e in differenti zone della forma. Sci. Tecn. Latt. Cas. 59:507-528.

Turgay, M., S. Irmler, D. Isolini, R. Amrein, M. T. Fröhlich-Wyder, H. Berthoud, E. Wagner, and D. Wechsler. 2011. Biodiversity, dynamics, and characteristics of Propionibacterium freudenreichii in Swiss Emmentaler PDO cheese. Dairy Sci. Technol. 91:471-489.

Vacheyrou, M., A. C. Normand, P. Guyot, C. Cassagne, R. Piarroux, and Y. Bouton. 2011. Cultivable microbial communities in raw cow milk and potential transfers from stables of sixteen French farms. Int. J. Food Microbiol. 146:253-262.

Veaux, M., E. Neviani, G. Giraffa, and J. Hermier. 1991. Evidence for variability in the phenotypic expression of lysozyme resistance in Lactobacillus helveticus. Lait 71:75-85.

Wilkinson, M. G., T. P. Guinee, and P. F. Fox. 1994. Factors which may influence the determination of autolysis of starter bacteria during Cheddar cheese ripening. Int. Dairy J. 4:141-160.

Zago, M., M. E. Fornasari, L. Rossetti, B. Bonvini, L. Scano, and D. Carminati. 2007a. Population dynamics of lactobacilli in Grana cheese. Ann. Microbiol. 57:349-353.

Zago, M. V. Suarez, J. A. Reinheimer, D. Carminati, and G. Giraffa. 2007b. Spread and variability of the integrase gene in Lactobacillus delbrueckii ssp. lactis strains and phages isolated from whey starter cultures. J. Appl. Microbiol. 102:344-351. 